\title{
Carnotite Resources of the
}

Upper Group Area,

San Miguel County, Colorado

\section{Trace Elements Investigations Report 145}

UNITED STATES DEPARTMENT OF THE INTERIOR GEOLOGICAL SURVEY 


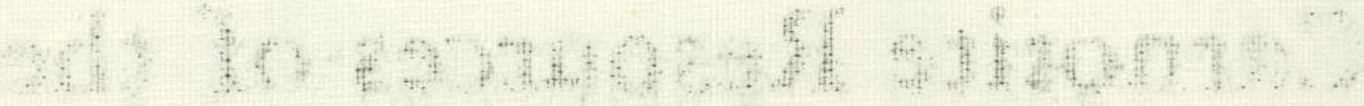

$$
\begin{aligned}
& \text {. BS1. 4010 1994प }
\end{aligned}
$$

obruglow pundo nugh mse

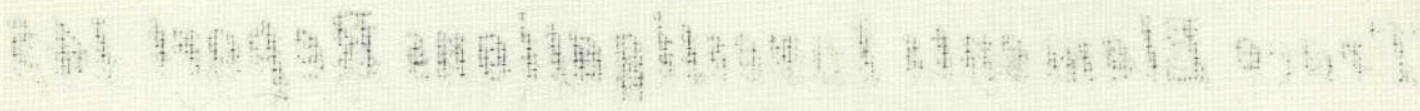

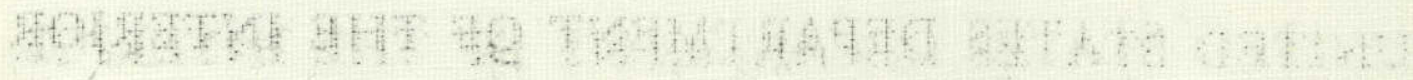

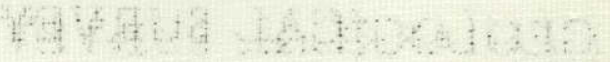


OFF tCIAL USE ONLY

This document consists of 53 pages, plus 2 figures, and 1 table; Series A. CATEGCRY V (Colorado Plateau drilling results)

UNITED STATES DEPARTMENT OF THE INTERIOR

GEOLOG ICAL SURVEY

CARNOTITE RESOURCES OF THE UPPER GROUP AREA

SAN MIGUEL COUNTY, COLORADO

By

C. F. Withington

July 1951

Trace Elements Investigations Report 145

OFF ICIAL USE ONLY 


\section{OFF ICIAL USE ONLY}

\section{2}

USGS - TEI Report 145

The distribution (Series A) of this report is as follows:

3 copies .... AEC, Washington (J. C. Johnson)

8 copies..... AEC, New York (P. L. Merritt)

I copy ....... AEC, Denver, Colo. (C. C. Towle, Jr.)

I copy ...... AEC, Spokane, Wash. (E. E. Thurlow)

2 copies ..... AEC, Grand Junction, Colo. (F. H. MacPherson)

1 copy ...... AEC, Grand Junction, Colo. (T. W. Oster)

I copy .... USGS, Washington (Mineral Deposits Branch)

1 copy ..... USGS, Washington (Geochemistry and Petrology Branch)

1 copy ..... USGS, Washington (Geophysics Branch)

1 copy ...... USGS, Washington (V. E. McKelvey)

I copy ...... USGS, Denver, Colo. (I. R. Page)

1 copy ....... USGS, Denver, Golo. (J. Fred Smith, Jr.)

3 copies..... USGS, Grand Junction, Golo. (R. P. Fischer)

4 copies . . . USGS, Washington (TEPCO)

(Including master copy) 
CONTENTS

\begin{abstract}
and summary ................. 5
Introduction .................... 7

Geology..................... 11

Ore deposits ...................... 12

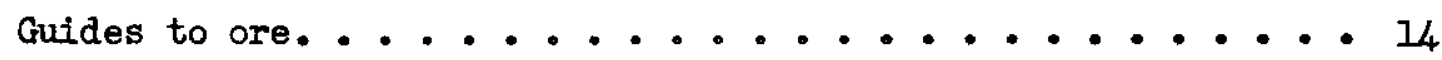

Geologicel Survey exploration. . . . . . . . . . 16

Reserves ................... 17

Indicated and inferred reserves . . . . . . . 18

Definitions. . . . . . . . . . . . 18

Thickness cutroff. . . . . . . . . . 29

Grade cut-offs............... 20

Calculation of tonnage ............. 21

Calculation of grade ............ 22

Reserve blocks ............ 23

Potential reserves. ............... 23

Plans and recommendations.............. 24
\end{abstract}


ILLUSTRATIONS

Page

Figure 1. Index map of part of the Colorado Plateau, showing the location of the Upper group area, San Miguel County, Colorado .........

2. Map of the Upper group area, San Miguel County, Colorado............... In envelope

3. Geologic sections of the Upper group area, San Miguel County, Colorado........... In envelope

\section{TABLES}

Table 1. Summary of indicated and inferred reserves, showing pounds of contained $\mathrm{U}_{3} \mathrm{O}_{8}$ and $\mathrm{V}_{2} \mathrm{O}_{5}$, Upper group area, San Miguel County, Colorade. ......... 8

2. Indicated and inferred reserves of the Upper group area, San Miguel County, Colorado. . . . . In envelope

3. Assay and gamma-ray data, Upper group area, San Miguel County, Colorado ........... 25-53 


\title{
OFF ICIAL USE ONLY
}

5

\author{
CARNOTITE RESOURCES OF THE UPPER GROUP AREA \\ SAN MIGUEL COUNTY, COLORADO \\ By \\ C. F. Withington \\ ABSTRACT AND SUMMARY
}

The Upper group area, which consists of 10 Govermment claims and adjoining public land, is 2 miles southeast of Slick Rock, San Miguel County, Colo., in unsurveyed secs. 5 and 6, T. 43 N., R. 18 W., New Mexico principal meridian. The area is equidistant from mills at Monticello, Utah, and Naturita, Colo. Both mills are reached by about 45 miles of all-weather roads.

About 2,700 tons of carnotite ore was produced from the area between 1921 and 1943 (tons used in this report are short tons). This ore had an estimated average grade of 0.25 percent $\mathrm{U}_{3} \mathrm{O}_{8}$ and 1.7 percent $\mathrm{V}_{2} \mathrm{O}_{5}$.

The ore deposits are in the top sandstone stratum of the Salt Wash sandstone member of the Upper Jurassic Morrison formation. The mincipal ore-bearing minerals, which mainly impregnate the sandstone, consist of uranium-bearing carnotite and a micaceous vanadium-bearing mineral called "roscoelite." The deposits are mostly in small podlike masses celled "rolls." The size of the 
rolls ranges from less than 50 to more than 1,500 tons each. The long axes of the rolls have a dominant northeasterly to easterly trend. Exploration by the Geological Survey was done on behalf of the Atomic Energy Conmission to test unexplored ground for new deposits of carnotite ore and to gain a better appraisal of the reserves in the area. From 1948 to 1950,186 diamond-drill holes were completed for a total of 14,577 feet..

The areas of favorable sandstone were found and defined by holes drilled 300 to 500 feet apart. Altered mudstone, carbonaceous material in the sandstone, and color of the sandstone were used to determine the favorability of the sandstone. Within areas containing favorable sandstone holes were drilled on 100- to 150-foot centers to find deposits. Where deposits were found more than 20 feet below the surface, they were roughly outlined by holes drilled on 50- to 75foot centers. Deposits discovered within 20 feet of the surface were not outlined.

Reserves in deposits found by the drilling are classed as indicated and inferred, whereas those reserves that are predicted solely on geologic evidence are classed as potential. Indicated reserves computed at the highest thickness and grade cut-offs ( 1 foot or more thick and 0.10 percent $\mathrm{U}_{3} \mathrm{O}_{8}$ or 1.0 percent $\mathrm{V}_{2} \mathrm{O}_{5}$ ) total 5,000 tons, averaging 0.19 percent $\mathrm{U}_{3} \mathrm{O}_{8}$ and 1.6 percent $\mathrm{V}_{2} \mathrm{O}_{5}$. Inferred reserves computed at the same cut-offs total 3,500 tons, averaging 0.22 percent $\mathrm{U}_{3} \mathrm{O}_{8}$ and 1.7 percent $\mathrm{V}_{2} \mathrm{O}_{5}$. Both the indicated and inferred 


\section{OFFICIAL USE ONLY}

\section{7}

reserves, as well as the pounds of contained $\mathrm{U}_{3} \mathrm{O}_{8}$ and $\mathrm{V}_{2} \mathrm{O}_{5}$, are summarized in table I. Potential reserves are predicted to total about 1,500 tons, averaging about 0.20 percent $\mathrm{U}_{3} \mathrm{O}_{8}$ and 1.6 percent $\mathrm{V}_{2} \mathrm{O}_{5}$. Most of the potential reserves are expected to be in amall scattered deposits within 20 feet of the surface.

No additional diamond drilling by the Coological Survey is plannad in the Upper group area. Several specific localities, principally in the central part of the area, are recommended for further exploration by jackhammer and wagon drilling by lessees and operators.

\section{INTRODUCTION}

The Upper group area is one of several significant uranium-producing areas near Slick Rock, San Miguel County, Colo. (fig. 1). It is about 2 miles southeast of Slick Rock, in parts of unsurveyed secs. 5 and 6, T. 43 N., R. 18 W., New Mexico principal meridian (figs. I and 2). The area, comprising about 250 acres, includes 10 Government claims and adjoining public land. Altitudes of the area range from 5,700 to 6,200 feet. Access is by 1 mile of unimproved road that connects with Colorado Highway 80 about 1 mile southeast of Slick Rock. The Upper group is about $45 \mathrm{miles}$ by all-weather road from both the Atomic Energy Commission's mill at Monticello, Jtah, and the Vanadium Corp. of America's mill at Naturita, Colo.

Mining and drilling can be carried on in the area throughout the year, as the climate is semi-arid, with mild winters and hot, dry 
Table 1.--Summary of indicated and inferred reserves $J$, showing pounds of contained $\mathrm{U}_{3} \mathrm{O}_{8}$ and $\mathrm{V}_{2} \mathrm{O}_{5}$, Upper group area, San Miguel County, Colo. (AlI reserves attributed to U.S.G.S. drilling).

\begin{tabular}{|c|c|c|c|c|c|c|}
\hline \multirow{5}{*}{ 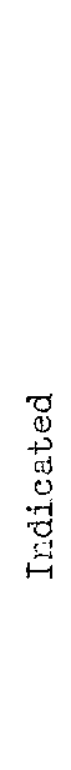 } & \multirow{2}{*}{$\begin{array}{l}\text { Grade } \\
\text { Cut-off }\end{array}$} & \multirow{2}{*}{$\begin{array}{l}\text { Short } \\
\text { tons }\end{array}$} & \multicolumn{2}{|c|}{ Percent } & \multicolumn{2}{|c|}{ Pounds contained } \\
\hline & & & $\mathrm{U}_{3} \mathrm{O}_{8}$ & $\mathrm{~V}_{2} \mathrm{O}_{5}$ & $\mathrm{U}_{3} \mathrm{O}_{8}$ & $\mathrm{v}_{2} \mathrm{O}_{5}$ \\
\hline & $\begin{array}{l}0.10 \% \mathrm{U}_{3} \mathrm{O}_{8} \\
\text { or } \\
1.0 \% \mathrm{~V}_{2} \mathrm{O}_{5}\end{array}$ & 5,000 & 0.19 & 1.6 & 19,000 & 160,000 \\
\hline & $\begin{array}{l}0.05 \% \mathrm{U}_{3} \mathrm{O}_{8} \\
\text { or } \\
0.5 \% \mathrm{~V}_{2} \mathrm{O}_{5}\end{array}$ & 8,000 & 0.13 & 1.2 & 20,800 & 192,000 \\
\hline & $\begin{array}{l}0.02 \% \mathrm{U}_{3} \mathrm{O}_{8} \\
\text { or } \\
0.2 \% \mathrm{~V}_{2} \mathrm{O}_{5}\end{array}$ & 17,700 & 0.07 & 0.7 & 24,800 & 248,000 \\
\hline \multirow{3}{*}{ 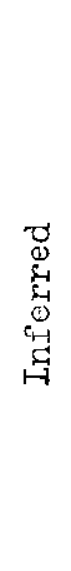 } & $\begin{array}{c}0.10 \% \mathrm{U}_{3} \mathrm{O}_{8} \\
\text { or } \\
1.0 \% \mathrm{~V}_{2} \mathrm{O}_{5}\end{array}$ & 3,500 & 0.22 & 1.7 & 15,400 & 119,000 \\
\hline & $\begin{array}{l}0.05 \% \mathrm{U}_{3} \mathrm{O}_{8} \\
\text { or } \\
0.5 \% \mathrm{~V}_{2} \mathrm{O}_{5}\end{array}$ & 7,000 & 0.13 & 1.0 & 18,200 & 140,000 \\
\hline & $\begin{array}{l}0.02 \% \mathrm{U}_{3} \mathrm{O}_{8} \\
\text { or } \\
0.2 \% \mathrm{~V}_{2} \mathrm{O}_{5}\end{array}$ & 21,600 & 0.06 & 0.5 & 25,900 & 216,000 \\
\hline
\end{tabular}

$\perp$ One foot or more thick 

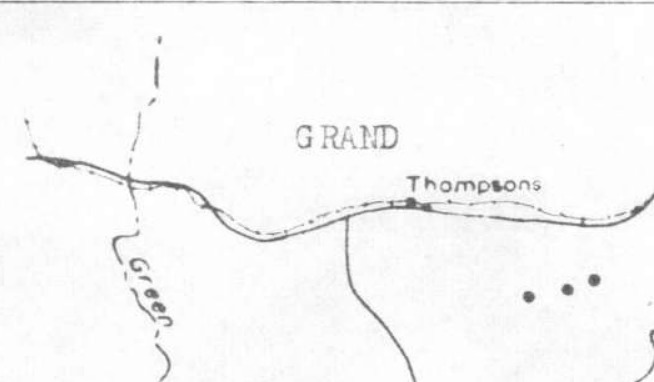

(a)
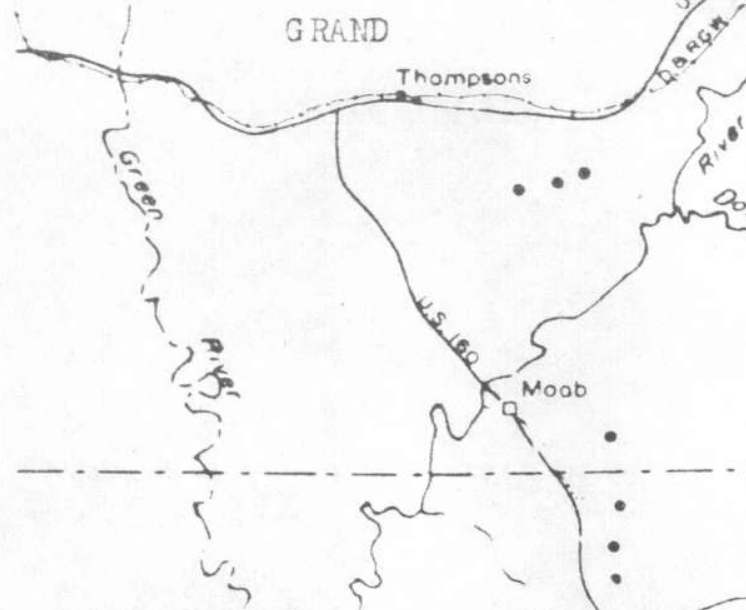

TAYNE
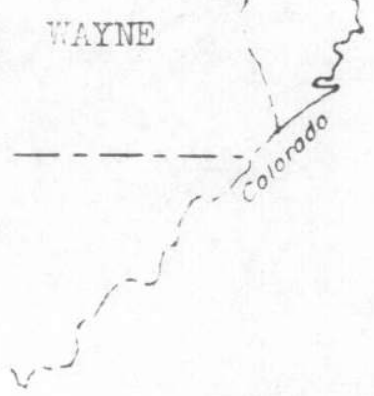

SAN JUAN

1

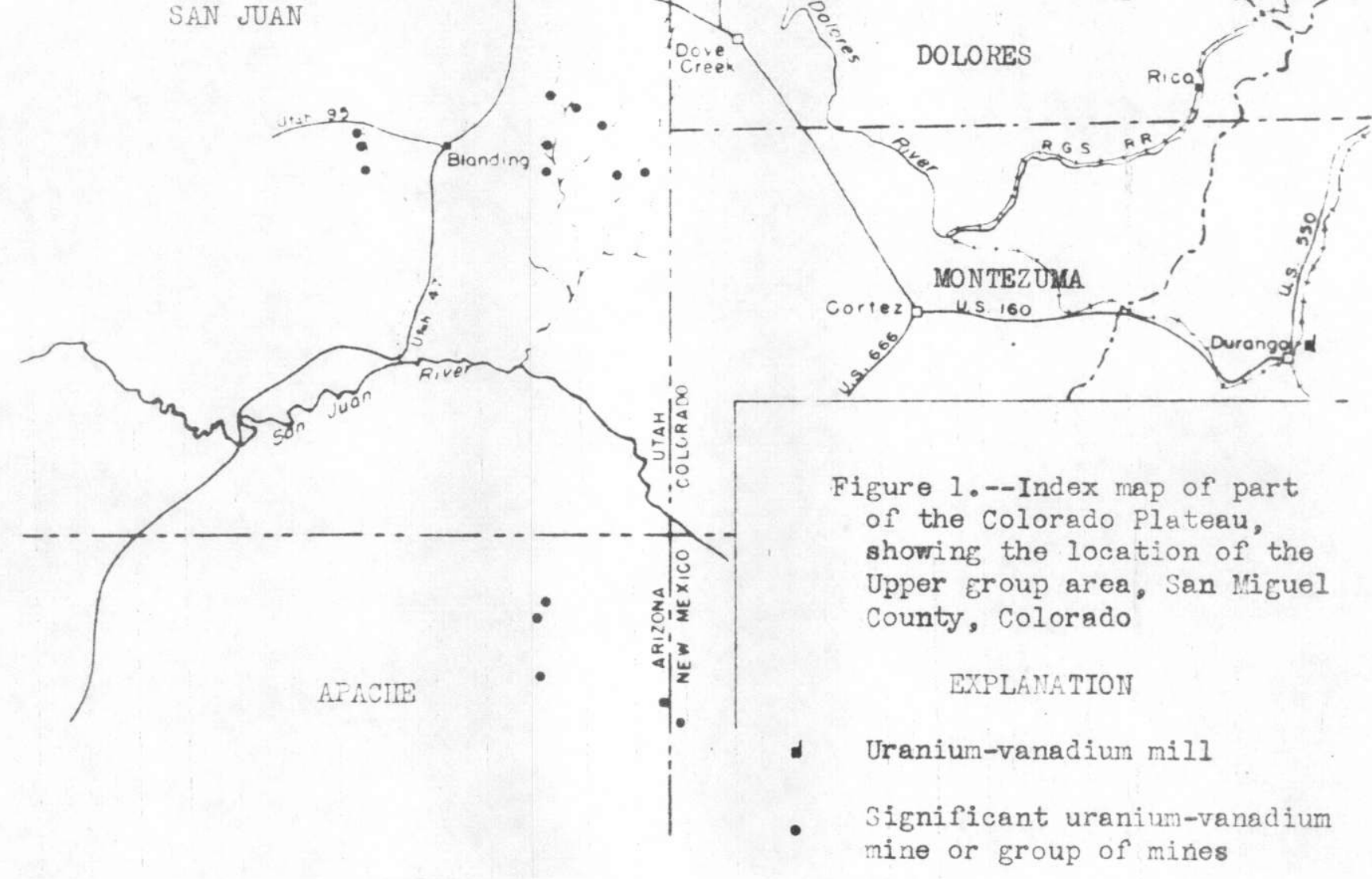


summers. The nearest water supply is the Dolores River, about It miles by road from the Jpper group. The altitude of the river at this point is about 5,400 feet.

Although records ompiled by the Geological Survey show no production from the Upper group before 1921, a few tons of ore probably were mined before that time. From 1921 to 1943, the last year of mining on the Upper group, about 2,700 tons of carnotite ore was produced, having an estimated average grade of 0.25 percent $\mathrm{U}_{3} \mathrm{O}_{8}$ and 1.7 percent $\mathrm{V}_{2} \mathrm{O}_{5}$ (tons in this report are short tons).

No definite data on the ownership of the claims of the Upper group before 1940 are available. In November 1940, the North Continent Mines, Inc. made a survey to patent 8 of the 10 claims. The 2 unpatented claims, the Black Belle and the Blue Bird, were located a few months later. In 1943, the ownership of the 10 clajms was transferred by quitclaim deed to the Union Mines Development Corp., which held them until 1949. In February 1949, the claims were purchased by the U. S. Covermment, the present owmer.

Diamond drilling was undertaken in 1948 by the Geological Survey, on behalf of the Atomic Energy Comission, in order to explore untested ground for new deposits of carnotite ore, and to obtain a better appraisal of the reserves. The only drilling prior to this time consisted of a few jackhammer holes drilled by the North Continent Mines, Inc. The Geological Survey completed 186 diamond-drill holes from June 1948 to April 1950, for a total of 14,577 feet. 


\section{GEOLOGY}

Exposed rocks in the Upper group area consist of the Brushy Basin shale member and the underlying Salt Wash sandstone member of the Upper Jurassic Morrison formation. These rocks, which dip $8^{\circ} \mathrm{NE} .$, form a small cuesta on which the Upper group lies.

The Brushy Basin shale member is composed of red-brown to graygreen mudstone beds 25 to 75 feet thick, containing interbeds of mediumto coarse-grained, red-brown sandstone, 10 to 25 feet thiok. Within the sandstone beds are small lenses of red chert conglomerate. The mudstone forms steep slopes that are capped by the sandstone beds. Recent erosion has removed the Brushy Basin from much of the area.

The Salt Wash sandstone member consists of three or more massive sandstone strata, which were probably deposited by meendering streams on a broad plain of low relief. Each stratum is composed of an acomation of lenses which were deposited in the channels of the aggrading streams. The combined thickness of these lenses ranges from 25 to 90 feet. The lenses are made up of light- to red-brown and light-gray, fine- to medium-coarse-grained quartz sandstone, which generally is cross-bedded. Layers of mudstone, 10 to 50 feet thick, are interbedded with the massive sandstone strata. The mudstone is dominantly red-brown, except at the contact of the mudstone and the sandstone, where it is generelly graygreen. The gray-green muastone ranges in thickness from a thin film to about 3 feet. It is most abundant near the base of the top sandstone 
stratum. All known carnotite deposits of comnercial grade and thickness in the Upper group are in the top sandstone stratum which is called the "ore-bearing sandstone."

Within the ore-bearing sandstone are thin seams of gray-green mudstone as well as small, gray-green mudstone-pebble conglomerates. Fossil plant remains, which have been compressed into thin seams of carboneceous material, are found associated with the mustone seems and conglomerates. A few fossil logs are also present in the sandstone.

The contact between the Salt Wash and the Brushy Basin members is the approximate top of the ore-bearing sandstone as shown on figure 2.

ORE DEPOSITS

The uranium- and vanadium-bearing minerals usualiy impregnate the ore-bearing sandstone, but in places they are found associated with mudstone pebbles as well as in seams of mudstone and carbonaceous material.

The principal uranium-bearing mineral is carnotite, a bright-yellow powdery mineral, irregularly disseminated through the ore-bearing sandstone. It usually coats the sand grains, but is also found in fractures and associated with mudstone.

Vanadium is found principally in a hydrous-mica mineral, referred to as "roscoelite." It coats the sand grains and fills the pore spaces and imparts a greenish-gray to gray cast to the sandstone, which darkens as the vanadium content increases. Other vanadium-bearing minerals 
found are corvusite, a massive, blue-black mineral, and vanoxite, a black, minutely crystalline mineral.

Three main types of deposits are found in the Upper group area. The first type consists of finely disseminated uranium- and vanadiumbearing minerals widely scattered in the ore-bearing sandstone. This type is usually found in fine-grained, indurated, gray sandstone. No deposits of commercial grade and thickness have been found in this type of sandstone.

The second type of deposit is associated with the contact of the sandstone and the underlying mudstone. The thickness of the mineralized material of this type ranges from 1 to 6 inches, equally divided between the sandstone and the mudstone. This mineralized material may have been carried by recent ground waters that migrated downward to the mudstone, where the mineralized material was concentrated. No deposits of this type have been found that are of commercial grade and size.

The third type of deposit is the most important. It consists of uranium- and vanadium-bearing minerals which are concentrated in thin seams that are found scattered anywere in the ore-bearing sandstone. The seams range from a few inches thick, to a foot or more thick in places, where they form podlike masses called "rolls." These deposits conform to the bedding of the sandstone in general, but do not follow the bedding or minor lensing in detail. The long axes of the rolls generally have a dominant east to northeast orientation. 
The rolls in the Upper group area are usually isolated bodies averaging about 75 feet 1ong, 15 feet wide, and 2 feet thick. In some places, tabular layers of mineralized rock less than a foot thick connect adjacent rolls. The rolls are generally less well developed in the area than in other parts of the Colorado Plateau.

The uranium- and vanadium-bearing minerals in the first and third types of deposits listed above probably were precipitated from ground water shortly after the deposition of the ore-bearing sandstone. The solutions probably were controlled by the local sedimentary structures, and probably were confined chiefly to the thicker parts of the ore-bearing sandstone. No regional structural control for the deposition of the uranium- and vanadium-bearing minerals is apparent.

\section{GUDES TO ORE}

The favorability of the drilled sandstone was determined by the criteria developed by the Geological Survey to guide exploration on the Colorado Plateau /. Of the criteria used, the most useful was the amount

/ Blackman, Doris H., Geologic guides to carnotite deposits on the Colorado Plateau: U. S. Geol. Survey Trace Elements Memorandum Rept. 170, August 1950.

of gray-green mudstone both immediately below, and included in, the sandstone. The mudstone probably was altered from its original red-brown color to gray-green by migrating ground water. The thickness of the altered basal mudstone probably reflects the amount of solutions that passed through the sandstone. 
Abundant carbonaceous material was also a useful criterion, as it indicated the presence of mineralized ground nearby. The carbonaceous material may have acted as a catalyst in the precipitation of the urantum and vanadium-bearing minerals from the ground water.

A third criterion used was the color of the sandstone. Lightbrown sandstone with abundant Iimonite-colored spots was more favorable than red-brown sandstone. The color of the sandstone probably was ariginally red-brown and has since been altered to light-brown by ground water. The limonite-colored spots possibly represent grains of magnetite or ilmenite that have been oxidized. A few black grains were noted which had limonite-colored halos. These halos may represent incomplete oxidation of the grains of iron-bearing minerals to limonite.

The above criteria are reliable only when taken as a whole, as no single one is sufficiently well defined to be used alone. Favorabijtity of the ore-bearing sandstone can be determined with these criteria by holes spaced 300 to 500 feet apart.

The most favorable sandstone found by diamond drilling on the Upper group is in the Big Four, Grant, and Sunnyside claims where most of the mineralized sandstone was found (fig. 2). The cemainder of the explored part of the area is classed as semi-favorable, even though some small deposits were found. Some sandstone in the northeastern and west-central parts of the area is unexplored, as the surface of the ground is accessible to drill rigs only with difficulty. Most of this sandstone is probably semi-favorable. 
GEOLOGICAL SURVEY EXPLORATION

The Geological Survey began diamond-drill exploration on the Upper group area in June 1948, when three holes were drilled on the Grant and Sunnyside claims to fulfill assessment requirements. In February and March 1949, 47 additional holes were drilled, and 136 more were added in February. March, and April 1950. In all, 186 holes were drilled, totaling 14,577 feet. The holes range in depth from 14 to 266 feet, and average 78 feet.

The plan of exploration consisted of drilling holes on $300-$ to 500-foot centers for geologic information. In ground determined as favorable from this wide-spaced drilling, holes were spaced 100 to 150 feet apart to search for deposits. Holes that cut mineralized rock generally were offset 50 to 75 feet, but when the mineralized sandstone was within 20 feet of the surface no offset holes were drilled and the area was left for further exploration by jackhammer drilling. The spacing of the holes depended to some extent on the accessibility of the ground to drill rigs.

Radiometric logs for the accessible holes were made by probing the holes with a gamma-ray logging unit. The results obtained are shown with the chemical assay data of the diamond-drill core samples in table 3.

of the 186 holes drilled, 139 (75 percent) are in mineralized rock, of which 43 (23 percent) are in material I foot or more thick, and either 
containing 0.10 percent or more $\mathrm{J}_{3} \mathrm{O}_{8}$ or 1.0 percent or more $\mathrm{V}_{2} \mathrm{O}_{5}$ by chemical assay of the drill core, or by registering gama-ray values greater than 0.09 percent equivalent $\mathrm{U}_{3} \mathrm{O}_{8}\left(-\mathrm{U}_{3} \mathrm{O}_{8}\right)$.

\section{RESERVES}

"Indicated" and "inferred" reserves are terms applied to the urentum and vanadium-bearing ore in deposits discussed in this report. These reserves are subdivided by thickness and grade cut-offs, and the method used in calculating them is explained below. Figures expressing the calculated tonnage and grade of the indicated and inferred reserves for each reserve block and for each grade cut-aff are given in table 2. The ground containing the reserve units or blocks and the geologic sections showing the position of the mineralized rock, are shown in figures 2 and 3. Besides the known deposits, there probably are others which have not yet been found, but whose existence is predicted from geologic evidence only. The term "potential" reserves is applied to these deposits. Potential reserves are discussed elsewhere in this report.

Reserves are not classified in this report according to their availability to mining, though consideration is given to the 1950 mining and milling practices in selecting the highest grade and thickness cut offs. This was done to obtain figures for one category of reserves that would express as nearly as possible the tonnage and grade of the material that might actually be mined profitably under 1950 conditions. 
A summary of indicated and inferred reserves in this category and the reserves in two additional categories of lower grade appear in table $I$. A more detailed breakdown by grade and thickness cut-offs, and by unit or block number, is given in table 2 .

Grade and thickness of reserves found by diamond drilling were determined from chemical assays.

Indicated and inferred reserves

Definitions

Reserves which have been calculated from diamond-drill data are divided into two classes--indicated and inferred. Indicated reserves

\footnotetext{
I The definitions used here for indicated and inferred reserves are abstracted from the definitions adopted by the Bureau of Mines and the Geological Survey in April 1943.
}

are those for which the grade is computed from diamond-drill hole semples and production data of the area, and for which the tonnage is computed by projection for a reasonable distance on geologic evidence from drillhole data. Reserves that can be classed as "measured" are included with the indicated reserves. This was done because carnotite ore has erratic variations in thickness and grade within short distances from sample points and, as a single sample probably would not contain the same proportion of uranium- and vanadium-bearing material as the reserve unit, the amount of reserves that can be calculated within a small limit of error is so small as to be nearly negligible.

\section{OFF ICIAL USE ONLY}


Inferred reserves are those for which quentitative estimates are based largely on broad knowledge of the geologic character of the deposits and for which there are few, if any, samples.

Because of the variations in thickness and grade of reserve units and the scarcity of sample data, the indicated reserves in any single reserve block might actually amount to as much as twice, or as little as one-half, the calculated tonnage. The inimit of error of the total tonnage figures for inferred reserves, of course, is probably higher than for indicated reserves. The limit of error in the celculated or estimated grade for both indicated and inferred reserves is probably somewhat smaller than the limit of error in the tonnage figures.

\section{Thickness cut-off}

Although mining practices differ from place to place within the region, as well as with individual operators, under 1950-5l mining conditions most ore bodies of average grade are being mined to where they pinch to a layer about I foot thick. Reserves, therefore, are calculated with a thickness cut-off of 1 foot. Layers of mineralized material less than I foot thick are mined in places if the grade is high. As only a few drill holes in the Upper group area, however, are in high-grade layers of mineralized material less than 1 foot thick, the tonnage of this minable material is so small as to be negligible, and for that reason, no reserves of this cut-off are calculated. 


\section{OFTICIAL USE ONLY}

Grade cut-offs

The deposits contain two metals of value, uranium and vanadium. In the Upper group area, the ratio of the oxides of these metals, $\mathrm{U}_{3} \mathrm{O}_{8}$ and $\mathrm{V}_{2} \mathrm{O}_{5}$, is about $1: 8$, as estimated from past production rocords and drill-core assays. The two metals vary in ratio between samples within the same deposit, so that the assay of a single sample from a deposit does not necessarily represent the metal ratio or grade of other parts of the same deposit. Knowing this by experience, the miner will drive to a drill hole that shows a good value in vanadium, even though the uranium content is negligible. Thus, the material in the vicinity of a sample must be classed as a reserve, even though the sample shows a value for only one metal. Furthermore, with the amendments to the 1949 price schedules for ore $J$, the vanadium content

」Domestic Uranium Program C1rcular 5 Revised, part 60-Domestic Uranium Program, Atomic Energy Commission, Washington, D. C., February 26, 1951 .

of Upper group ore containing the normal metal ratio constitutes about two-fifths of the market velue of the ore. Thus, both metals must be considered in reserve appraisals and in selecting grade cut-offs.

Three grade cut-offs are used for reserves 1 foot or more thick. The highest cut-off used-0.1 percent $\mathrm{U}_{3} \mathrm{O}_{8}$ or 1.0 percent $\nabla_{2} \mathrm{O}_{5}$-corresponds to the Atomic Energy Commission's purchase cut-off for uranium and the Monticello, Jtah, mill cut-off for vanadium. Reserves are also 
figured on a lower cut-off-0.05 percent $\mathrm{J}_{3} \mathrm{O}_{8}$ or 0.5 percent $\mathrm{V}_{2} \mathrm{O}_{5}$-on the possibility that conditions in the future might demand or permit the mills to accept lower-grade ore. The calculations of reserves at

a still lower cutmoff-0.02 percent $\mathrm{U}_{3} \mathrm{O}_{8}$ or 0.2 percent $\mathrm{V}_{2} \mathrm{O}_{5}$-has little or no practical value, but it is done to obtaln a better idea of the tonnag of this weakly mineralized material and the amount of metal contained in it.

\section{Calculation of tonnage}

The method used for calculating the volume, and hence the tonnage, of a reserve unit I foot or more thick is based on the premise that the reserve unit is a tabular mass. The average thickness of the drillhole samples that can be combined within the specified grade class is assumed to be the average thickness of the reserve unit.

By definition, the tonnage of indicated reserves $n_{\ldots, \ldots i s}$ computad by projection for a reasonable distance on geologic evidence." In the Upper group indicated reserves are projected between drill holes no more than 50 feet apart, and are not projected more than 25 feet beyond drill holes where the edge of the deposit has not been located. Reserves are classed as inferred rather than indicated if the profention exceeds these lengths. Inferred reserves are projected to the assumed limits of the deposit, as determined by geologic evidence and interpretation. 
OFFICIAL USE ONLY

A constant of 14 cubic feet per ton is used to calculate tonnage.

$$
\text { Calculation of grade }
$$

The average grade of the indicated reserves is calculated by weighting the assay values of all samples that qualify as reserves within the grade and thickness limits. As strict grade cut-offs are used, it must be expected that the average grade assigned to a reserve unit will be somewhat higher than the average grade of the ore that will be mined from it, owing to the unavoidable dilution of the ore with waste and low-grade material during mining. On the other hand, the tonnage assigned to a unit should be somewhat lower than the tonnage mined from it, owing to the increment of waste and low-grade material.

The calculation of the grade of the inferred reserves is nearly the same as that for the indicated reserves in the same unit. Fxception is made when the assay from a single drill hole in a reserve unit shows an abnormally high uranium content. It is assumed, thereby, that the sample is not representative of the reserve unit, and, therefore, an estimated grade for the uranium content is assigned which is near the normal ratio of 1:8 with the vanadium content of the sample. 


\section{OFFICIAL USE ONLY}

Reserve blocks

Messes or units of mineralized rock that constitute an indicated or inferred reserve, as defined by the thickness and grade cut-offs, are called reserve blocks. The geometric limits of reserve blocks are determined by the rules used in calculating reserves (see above). The exact positions of the block are not shown on the map though the carnotite-bearing sandstone that contains the blocks is designated by block numbers. Where mineralized areas overlap, even though they contain two or more masses, a single reserve block is assigned, and the total tonnage of these masses as well as their weighted average grade are shown in table 2 .

\section{Potential reserves}

Potential reserves comprise the material in deposits above specific thickness and grade cut-offs, which are predicted solely on geologic evidence. In the Upper group area about 1,500 tons of potential reserves of material above a thickness cut-off of 1 foot and a grade cut-off of 0.10 percent $\mathrm{U}_{3} \mathrm{O}_{8}$ or 1.0 percent $\mathrm{V}_{2} \mathrm{O}_{5}$ are predicted. This material probably will have about the same average grade as the indicated and inferred reserves ( 0.20 percent $\mathrm{U}_{3} \mathrm{O}_{8}$ and 1.6 percent $\mathrm{V}_{2} \mathrm{O}_{5}$ ). About 500 to 1,000 tons of these reserves may be found in the Grant, Sunnyside, and Big Four claims in deposits that average 100 tons or less in size. The remainder of these reserves are predicted for the 
semi-favorable and unexplored southern part of the area(fig. 2), where the reserves are expected to be in masses averaging less than 50 tons in size, many of which probably lie within 20 feet of the surface.

PLANS AND RECOMINENDATIONS

No further diamond drilling is planned in the Upper group area by the Geological Survey. In the iavorable sandstone, most of the deposits containing more than 100 tons of reserves above the highest grade cutoff have been discovered. The areas classed as semi-fivorable probably contain some additional scattered reserves that are expected to average less than 50 tons each--an amount too small to merit search by diamond driliinE.

Prospecting by jackhamer drilling is recommended for lessees and operators in the vicinity of holes in mineralized sandstone that is within 20 feet of the surface (fig. 2). In addition, prospecting by jackhammer drilling is recommended in the Black Fox, Canyon Viev, and University claims, where several small deposits probably lie within 20 feet of the surface. Wagon drilling may be done economically in the vicinity of holes 139 and 145, where the base of the ore-bearing sandstone is 75 to 80 feet below the surface. 
Table 3.--Assay and gamma-ray data, Upper group area, San Niguel County, Colorado

Geological Survey exploration, June 1948-March 1950; drill holes are shown on figure 2 with symbols o, $\beta$, and • (Assays by Geological Survey, except as indicated below).

Assay data listed under "block" (i.e. block 1, block 2, etc.) are within blocks of calculated reserves.

Assay data listed under "other holes" are from holes within areas for which no reserves were calculated because the samples recoveredwere too thin or too weakly mineralized to qualify for the selected grade and thickness cut-offs.

Gamma-ray intensity obtained by probing of drill holes with radiometric logging unit. Abbreviations used for gamma-ray intensity:

W Weak; concentrations of radioactive material in which the equivalent $\mathrm{U}_{3}$ Co content probably ranges from $0.05 \%$ to $0.09 \%$.

$S$ Strong; concentrations of radioactive material in which the equivalent $\mathrm{U}_{3} \mathrm{O}_{8} \mathrm{content}$ probably ranges from $0.10 \%$ to $0.99 \%$.

VS Tery strong; concentrations of radioactive material in which the equivalent $\mathrm{U}_{3} \mathrm{O}_{8}$ content probably is $1.0 \%$ or more.

Gamma-ray intensities significantly greater than the background effect of barren rock, but less than $0.05 \%$ equivalent $\mathrm{U}_{3} \mathrm{O}_{8}$ are not listed. Holes with intensities no greater than the background effect of barren rock are listed as "barren." 
Table 3.--Assay and gamma--ray data, Upper group area, San Miguel County, Colorado--Continued

Note: Holes shown to be barren by both assay and gamna-ray data are omitted from this table.

$<\quad$ Less than.

I. No mineralized sample, or sample deficient, probably because of incomplete core recovery.

2/ Appreciable gamma-ray inconsity attributed to contamination along walls of hole.

3) Assay by American Smelting and Refining Co., Grand Junction, Colo.; all others by the Geological Survey.

4 Most of sample in mudstone. Other samples are in sandstone.

5 Sludge sample.

\begin{tabular}{llll} 
Hole No. Depth in feet & Assay data \\
\hline From & Thickness & Percent \\
(feet) & $\mathrm{U}_{3} \mathrm{O}_{8}$ & $\mathrm{~V}_{2} \mathrm{O}_{5} \mathrm{CaCO}_{3}$
\end{tabular}

\begin{tabular}{|c|c|c|}
\hline Gamma-ray & Depth in feet & Thickness \\
\hline intensity & From $\quad$ To & (feet) \\
\hline
\end{tabular}

Block 1 (Big Four, Canyon View, Grant, Sunnyside claims, and public land)

2

5

6

8

$$
\begin{array}{r}
5.4 \\
65.9
\end{array}
$$$$
\begin{array}{r}
5.8 \\
66.5
\end{array}
$$$$
\begin{aligned}
& 0.4 \\
& 0.6
\end{aligned}
$$$$
0.003
$$$$
0.021
$$

$40.3 \quad 40.6$

40.6

$$
42.9
$$$$
43.7
$$$$
42.9
$$

44.5

30.1

40.1

52.6

53.4

28.5

29.0

29.9

30.1
29.0

29.9

30.1

31.7

$\begin{array}{lllr}0.3 & 0.025 & 0.04 & 10.3 \\ 2.31 / & -0.021 & 0.21 & 2.9 \\ 0.31 / & 0.021 & 0.01 & 10.2 \\ 0.81 / & 0.022 & 0.01 & \end{array}$$$
10.01 / \ldots
$$$$
0.0
$$$$
2.0
$$

$0.5 \quad 0.015$

$0.93 / 0.22$

$0.2^{0} 0.03$

$\begin{array}{ll}1.6 & 0.013\end{array}$

0.73

2.25

0.20

0.08

1.1

0.2

0.1

4.8 intensity From

(feet) 
Table 3.--Assay and gamma-ray data, Upper group area, San Miguel County, Colorado--Continued

\begin{tabular}{cllll} 
& Assay data \\
Hole No. Depth in feet & Thickness & \multicolumn{3}{c}{ Percent } \\
\cline { 2 - 3 } & From feet) & $\mathrm{U}_{3} \mathrm{O}_{8}$ & $\mathrm{~V}_{2} \mathrm{O}_{5}$ & $\mathrm{CaCO}_{3}$
\end{tabular}

\begin{tabular}{lll}
\multicolumn{3}{c}{ Gamma-ray data } \\
\hline Gamma-ray & Depth in feet Thickness \\
intensity & From (feet)
\end{tabular}

Block 1 (Big Four, Canyon View, Grant, Sunnyside claims, and public land -- continued)

-

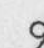

11

$\begin{array}{ll}54.4 & 54.7 \\ 55.1 & 55.4 \\ 55.6 & 56.8 \\ 31.2 & 31.9 \\ 31.9 & 32.4 \\ 52.2 & 52.9 \\ 55.4 & 60.4 \\ 63.4 & 63.9\end{array}$

0.3

0.3

1.24

0.0120 .03

$0.008 \quad 0.03$

5.3

5.7

0.7

$\begin{array}{lll}.7 & 0.021 & 0.96\end{array}$

0.53

0.7 .4

$0.5=$

0.0190 .02

0.5

0.019

0.01

1.4

1.7
4.3

4.3

12

$34.1 \quad 34.4$

$40.2 \quad 41.5$

65.0

0.3

$\begin{array}{ll}0.011 & 0.13\end{array}$

1.3
5.1

0.010

70.0

3

0.0

13

61.9

63.2

$50.7 \quad 52.9$

$55.8 \quad 56.0$

$57.7 \quad 57.9$

$78.7 \quad 79.2$

15

$\begin{array}{ll}27.7 & 28.2 \\ 28.2 & 28.6 \\ 28.6 & 29.1 \\ 29.1 & 30.0 \\ 30.0 & 30.8 \\ 31.0 & 35.0 \\ 35.0 & 36.3 \\ 59.6 & 60.3\end{array}$

\section{2}

0.2

0.2

0.5
0.015

0.0050 .44

$0.016 \quad 0.05$

$0.011 \quad 0.36$

$0.002 \quad 0.07$ $\begin{array}{llll}0.5 & 0.002 & 0.11 & \text { undet. }\end{array}$

$\begin{array}{lllll}0.43 / & 0.009 & 0.09 & 8.0\end{array}$

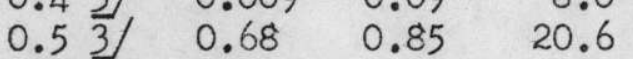

$\begin{array}{lllll}0.93 & 0.30 & 0.90 & 5.8\end{array}$

$\begin{array}{llll}0.8 & 0.087 & 0.17 & 4.4\end{array}$

$\begin{array}{llll}4.0 & 0.037 & 0.33 & 2.4\end{array}$

$\begin{array}{llll}1.3 & 0.012 & 0.05 & 2.7\end{array}$

$\begin{array}{llll}0.7 & 0.012 & 0.03 & 3.3\end{array}$ and (

$$
\begin{aligned}
& S \\
& W \\
& W \\
& W
\end{aligned}
$$

2)

$\begin{array}{lll}17.0 & 26.5 & 9.5\end{array}$

$\begin{array}{lll}31.0 & 32.5 & 1.5 \\ 51.2 & 52.2 & 1.0 \\ 56.2 & 56.8 & 0.6 \\ 62.2 & 63.3 & 1.1 \\ & & \\ & & \\ 67.3 & 69.4 & 2.1\end{array}$


Table 3.--Assay and gamma-ray data, Upper group area, San Miguel County, Colorado--Continued

\begin{tabular}{ccccc} 
Assay data \\
\hline
\end{tabular}

\begin{tabular}{lll}
\multicolumn{3}{c}{ Gamma-ray data } \\
\hline Gamma-ray & Depth in feet & Thickness \\
\cline { 9 - 9 } & From $\quad$ To feet)
\end{tabular}

Block 1 (Big Four, Canyon View, Grant, Sunnyside claims, and public land -- continued)
Q

$$
16
$$

$$
\begin{aligned}
& 26.0 \\
& 40.8 \\
& 41.2 \\
& 43.3
\end{aligned}
$$

$$
\begin{array}{ll}
26.6 & 0.6 \\
41.1 & 0.3
\end{array}
$$$$
41.7 \quad 0.3
$$$$
43.6
$$$$
\begin{aligned}
& 0.3 \\
& 0.3
\end{aligned}
$$$$
\begin{array}{ll}
0.008 & 0.06 \\
0.008 & 0.08
\end{array}
$$$$
\begin{array}{ll}
0.005 & 0.02 \\
0.020 & 0.08
\end{array}
$$$$
3.0
$$$$
2.9
$$

$\begin{array}{ll}17 \quad 70.8 \\ & 71.7\end{array}$

$$
\begin{aligned}
& 71.1 \\
& 72.0
\end{aligned}
$$$$
\begin{array}{ll}
0.34 \\
0.34
\end{array}
$$

$0.004 \quad 0.02$$$
\begin{aligned}
& 1.6 \\
& 3.9
\end{aligned}
$$

$$
\begin{aligned}
& 26.0 \\
& 33.5 \\
& 65.8
\end{aligned}
$$$$
\begin{array}{ll}
27.3 & 1.3 \\
34.7 & 1.2 \\
66.3 & 0.5
\end{array}
$$$$
66.3
$$$$
0.010
$$$$
\begin{aligned}
& 0.02 \\
& 0.04
\end{aligned}
$$$$
\begin{aligned}
& 8.2 \\
& 5.8
\end{aligned}
$$

19

13.4
13.9
33.1

13.9

0.5

$\begin{array}{ll}0.015 & 0.05 \\ 0.035 & 0.17\end{array}$

W

0.010

$$
\begin{aligned}
& 1.0 \\
& 1.8
\end{aligned}
$$

$\begin{array}{lll}0.020 & 0.13\end{array}$

$0.005 \quad 0.12$

$21.0 \quad 7.1$

$33.7 \quad 0.61$

$0.015 \quad 0.05$

0.0110 .07

1.1

41.9

43.2

1.3

0.009

0.04

2.5

1.9
7.8

W

0.9

21

$\begin{array}{llllll}57.9 & 58.1 & 0.2 & 0.009 & 0.04 & 0.9 \\ 31.3 & 32.2 & 0.9 & 0.03 & 0.18 & 4.9 \\ 32.2 & 33.2 & 1.0 & 0.19 & 1.26 & 1.0 \\ 33.2 & 35.1 & 1.95 / & 0.070 & 0.36 & 2.0 \\ 35.1 & 36.0 & 0.91 / & -\cdots & -\cdots & -- \\ 36.0 & 38.1 & 2.11 / 3 / 0.21 & 2.11 & 5.2 \\ & & & & & \\ 38.1 & 38.4 & 0.3 & 0.045 & 2.65 & 3.5 \\ 38.4 & 39.9 & 1.5 & 0.024 & 0.40 & 20.6\end{array}$

OFFICIAL USE ONLY 
Table 3.--Assay and gamma-rał data, Up̈per group area, San Miguel County, Colorado--Continued

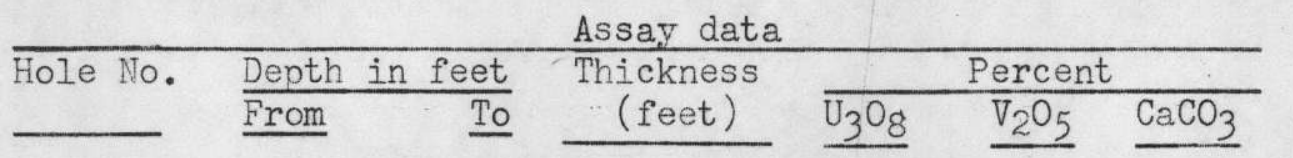

\begin{tabular}{lll} 
& Gamma-ray data & \\
\hline Gamma-ray & Depth in feet & Thickness \\
intensity & From $\quad$ To & (feet)
\end{tabular}

Block I (Big Four, Canyon View, Grant, Sunnyside claims and public land-- continued)

22

$\begin{array}{ll}16.3 & 17.7 \\ 28.3 & 28.9 \\ 29.3 & 30.8 \\ 31.1 & 31.4 \\ 31.7 & 33.2 \\ 38.0 & 38.4\end{array}$

24

26

27

29

$\begin{array}{rll}32.1 & 33.0 \\ 33.4 & 34.2 \\ 35.0 & 36.1 \\ 36.6 & 37.7 \\ 37.8 & 41.0 \\ 41.3 & 41.8 \\ & & \\ & & \\ & & \\ & 24.1 & 24.6 \\ 24.6 & 26.9 \\ 45.2 & 50.2 \\ 50.8 & 51.8\end{array}$

45.2

45.8

62.1

62.3

41.2

41.5

43.6

46.2

46.9

41.5

42.8

43.3

44.0

46.9

47.7

1.4
0.6
1.5
0.3
1.5
0.4

0.010

0.026

0.09

2.6

0.009

0.010

0.07

10.7

0.006

0.15

1.3

0.6

0.021

0.08

0.007

0.2

0.3

1.3

0.5

0.4

0.7

0.8

0.010

0.004

0.08

0.9

0.04

0.008

0.014

0.016

0.010

0.16

0.04

0.07
0.03

$0.03 \quad 5.0$

$0.00 \quad 4.1$

$0.20 \quad 5.3$

$$
0.9
$$

0.81

1.1

1.1

3.2

0.009

0.007

0.1

$0.06 \quad 9.7$

$\begin{array}{ll}0.08 & 14.8\end{array}$

0.012

0.025

$0.06 \quad 13.8$

$0.07 \quad 4.9$

0.5

0.010

$0.04 \quad 1.8$

$\begin{array}{llll}0.51 / & 0.16 & 0.42 & 8.7 \\ 2.31 / & 0.016 & 0.29 & 5.0 \\ 5.01 / & 0.022 & 0.05 & 7.8 \\ 1.0 & 0.0\end{array}$

OFFICIAL USE ONLY
Not probed

$\begin{array}{lll}60.3 & 61.2 & 0.9 \\ 40.0 & 41.5 & 1.5 \\ & & \\ 45.2 & 46.5 & 1.3 \\ 46.5 & 48.2 & 1.7\end{array}$

$\begin{array}{lll}33.5 & 34.5 & 1.0\end{array}$

$\begin{array}{lll}36.0 & 36.9 & 0.9\end{array}$

$\begin{array}{lll}20.7 & 21.4 & 0.7\end{array}$

$\begin{array}{lll}45.2 & 45.8 & 0.6\end{array}$ 
Table 3.--Assay and gamma-ray data, Upper group area, San Miguel County, Colorado--Continued

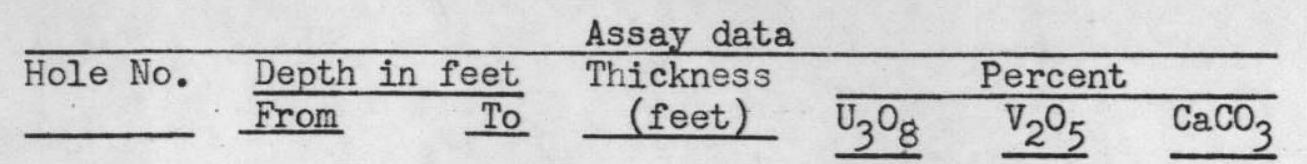

\begin{tabular}{l} 
Gamma-ray data \\
$\begin{array}{l}\text { Gamma ray } \\
\text { intensity }\end{array}$ Fropth in feet \\
\hline From Thekness \\
(feet)
\end{tabular}

Block I (Big Four, Canyon View, Grant, Sunnyside claims, and public land - continued)

\begin{tabular}{|c|c|c|c|c|c|c|c|c|}
\hline $\begin{array}{l}31.1 \\
35.4 \\
37.2 \\
38.7 \\
39.3 \\
39.9 \\
41.1\end{array}$ & $\begin{array}{l}35.1 \\
36.3 \\
38.7 \\
39.3 \\
39.9 \\
41.1 \\
42.1\end{array}$ & $\begin{array}{l}4.0 \\
0.9 \\
1.5 \\
0.6 \\
0.6 \\
1.2 \\
1.0\end{array}$ & $\begin{array}{l}0.023 \\
0.015 \\
0.052 \\
0.077 \\
0.14 \\
0.072 \\
0.016\end{array}$ & $\begin{array}{l}0.04 \\
0.04 \\
0.04 \\
0.23 \\
0.81 \\
1.02 \\
0.03\end{array}$ & $\begin{array}{l}2.4 \\
2.7 \\
3.7 \\
3.5 \\
3.0 \\
3.9 \\
2.6\end{array}$ & $\begin{array}{l}W \\
W\end{array}$ & $\begin{array}{l}32.0 \\
33.8\end{array}$ & $\begin{array}{l}32.5 \\
35.4\end{array}$ \\
\hline $\begin{array}{l}35.0 \\
36.5 \\
38.1\end{array}$ & $\begin{array}{l}36.5 \\
37.1 \\
39.0\end{array}$ & $\begin{array}{l}1.51 \\
0.6 \\
0.94\end{array}$ & $\begin{array}{l}0.025 \\
0.008\end{array}$ & $\begin{array}{l}-.09 \\
0.08\end{array}$ & $\begin{array}{r}7.0 \\
-1.4\end{array}$ & $\begin{array}{l}W \\
W\end{array}$ & $\begin{array}{l}35.0 \\
36.5\end{array}$ & $\begin{array}{l}35.8 \\
37.1\end{array}$ \\
\hline $\begin{array}{l}15.6 \\
48.9 \\
66.2 \\
69.2\end{array}$ & $\begin{array}{l}20.6 \\
50.3 \\
66.8 \\
69.5\end{array}$ & $\begin{array}{l}5.01 \\
1.4 \\
0.6 \\
0.3\end{array}$ & $\begin{array}{l}0.006 \\
0.037 \\
0.015\end{array}$ & $\begin{array}{l}\overline{0.19} \\
0.04 \\
0.04\end{array}$ & $\begin{array}{l}--.6 \\
4.6 \\
0.8 \\
0.4\end{array}$ & $\begin{array}{l}W \\
W \\
W\end{array}$ & $\begin{array}{l}19.5 \\
46.2 \\
65.0\end{array}$ & $\begin{array}{l}20.3 \\
48.1 \\
65.7\end{array}$ \\
\hline $\begin{array}{l}20.9 \\
36.8 \\
39.4 \\
69.2 \\
69.8 \\
70.7\end{array}$ & $\begin{array}{l}21.2 \\
37.1 \\
39.8 \\
69.5 \\
70.1 \\
71.0\end{array}$ & $\begin{array}{l}0.3 \\
0.3 \\
0.4 \\
0.3 \\
0.3 \\
0.3\end{array}$ & $\begin{array}{l}0.012 \\
0.002 \\
0.009 \\
0.015 \\
0.016 \\
0.04\end{array}$ & $\begin{array}{l}0.39 \\
0.07 \\
0.08 \\
0.07 \\
0.05 \\
0.16\end{array}$ & $\begin{array}{l}7.8 \\
0.8 \\
0.1 \\
2.9 \\
2.5 \\
3.4\end{array}$ & & & \\
\hline $\begin{array}{l}10.1 \\
15.1 \\
18.4 \\
25.1 \\
30.1 \\
53.2 \\
54.8 \\
56.0 \\
75.1\end{array}$ & $\begin{array}{l}15.1 \\
18.4 \\
19.4 \\
30.1 \\
45.1 \\
54.8 \\
56.0 \\
56.5 \\
80.1\end{array}$ & $\begin{array}{c}5.0 \mathrm{l} / \\
3.3 \mathrm{I} / \\
1.0 \mathrm{4} / \\
5.0 \mathrm{I} / \\
15.0 \mathrm{I} / \\
1.6 \\
1.2 \\
0.5 \\
5.0 \mathrm{~J}\end{array}$ & $\begin{array}{l}0.024 \\
0.053 \\
0.20 \\
0.061 \\
\end{array}$ & $\begin{array}{l}\overline{0.64} \\
\overline{0.0} \\
0.04 \\
0.04 \\
0.12 \\
\end{array}$ & $\begin{array}{r}\overline{10.2} \\
\overline{-} \\
\overline{2.5} \\
3.4 \\
2.8 \\
\end{array}$ & $\begin{array}{l}W \\
W \\
S \\
W \\
W \\
W \\
S \\
W \\
S\end{array}$ & $\begin{array}{l}13.6 \\
15.7 \\
17.4 \\
27.1 \\
34.4 \\
48.4 \\
52.8 \\
55.1 \\
75.8\end{array}$ & $\begin{array}{l}14.3 \\
17.4 \\
18.1 \\
29.4 \\
42.9 \\
52.8 \\
55.1 \\
64.1 \\
76.6\end{array}$ \\
\hline
\end{tabular}




\section{OFFICIAL USE ONLY}

31

Table 3.--Assay and gamma-ray data, Upper group area, San Miguel County, Colorado--Continued

\begin{tabular}{|c|c|c|c|c|c|c|}
\hline \multirow[b]{2}{*}{ Hole No. } & \multicolumn{3}{|c|}{ Assay data } & \multicolumn{3}{|c|}{ Garma-ray data } \\
\hline & $\begin{array}{l}\text { Depth in feet } \\
\text { From }\end{array}$ & $\begin{array}{c}\text { Thickness } \\
\text { (feet) }\end{array}$ & $\frac{\mathrm{Percent}}{\mathrm{V} \mathrm{C}^{-} \mathrm{C} \mathrm{CO}^{-}}$ & Gamma-ray & Depth in feet & Thickness \\
\hline
\end{tabular}

Block I (Big Four, Canyon view, Grant, Sunnyside claims, and public land -- continued)

47

$\begin{array}{llllll}23.9 & 24.4 & 0.5 & 0.048 & 0.47 & 3.3 \\ 24.4 & 24.8 & 0.4 & 0.19 & 0.52 & 2.7 \\ 24.8 & 25.6 & 0.8 & 0.38 & 2.14 & 1.8 \\ 25.6 & 27.0 & 1.4 & 0.016 & 2.19 & 2.2 \\ 29.5 & 30.6 & 1.1 & 0.012 & 0.05 & 4.0 \\ 30.6 & 32.5 & 1.9 & 0.037 & 0.56 & 3.7 \\ 32.5 & 33.0 & 0.54 / & 0.007 & 0.081 & 0.3 \\ 35.0 & 40.0 & 5.011 & -1.017 & -1.025 & -1.1 \\ 57.7 & 58.5 & 0.83 / & 0.017 & 0.025 & 2.1 \\ 64.8 & 65.1 & 0.3 & 0.021 & 0.03 & 1.4\end{array}$

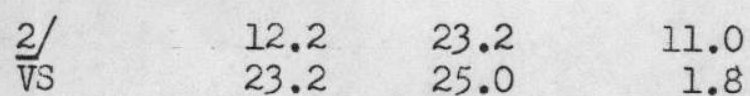

48

$\begin{array}{llllll}16.1 & 17.5 & 1.4 & 0.041 & 0.42 & 3.7 \\ 17.5 & 18.9 & 1.4 & 0.005 & 0.11 & 6.2 \\ 18.9 & 19.4 & 0.5 & 0.037 & 2.87 & 0.2 \\ 19.4 & 21.4 & 2.0 & 0.23 & 2.63 & 1.5 \\ 21.4 & 23.1 & 1.7 & 0.039 & 1.51 & 3.0 \\ 60.5 & 65.5 & 5.01 & \ldots\end{array}$

50

$\begin{array}{rllllr}31.2 & 32.1 & 0.94 / & 0.42 & 0.99 & 1.7 \\ 32.1 & 33.2 & 1.1 .1 & 0.034 & 0.15 & 3.6 \\ 33.2 & 33.6 & 0.4 & 0.15 & 0.92 & 1.7 \\ 33.6 & 34.2 & 0.6 & 0.14 & 0.84 & 50.4 \\ 34.2 & 36.5 & 2.3 & 0.055 & 0.29 & 50.5 \\ 36.5 & 37.2 & 0.7 & 0.22 & 1.88 & 1.3 \\ 37.2 & 37.8 & 0.6 & 0.064 & 0.91 & 6.4 \\ 37.8 & 40.1 & 2.3 & 0.027 & 0.11 & 50.8\end{array}$


Table 3.--Assay and gamma-ray data, Upper group area, San Miguel Counuy, Colorado-mContinued

\begin{tabular}{ccccc} 
Assay data & & Gamma-ray data \\
\hline Hole No. Deoth in feet & Thickness & Percent & Gama-ray & Depth in feet \\
\hline
\end{tabular}

Block I (Big Four, Canyon View, Grant, Sunnyside claims, and public land - continued)

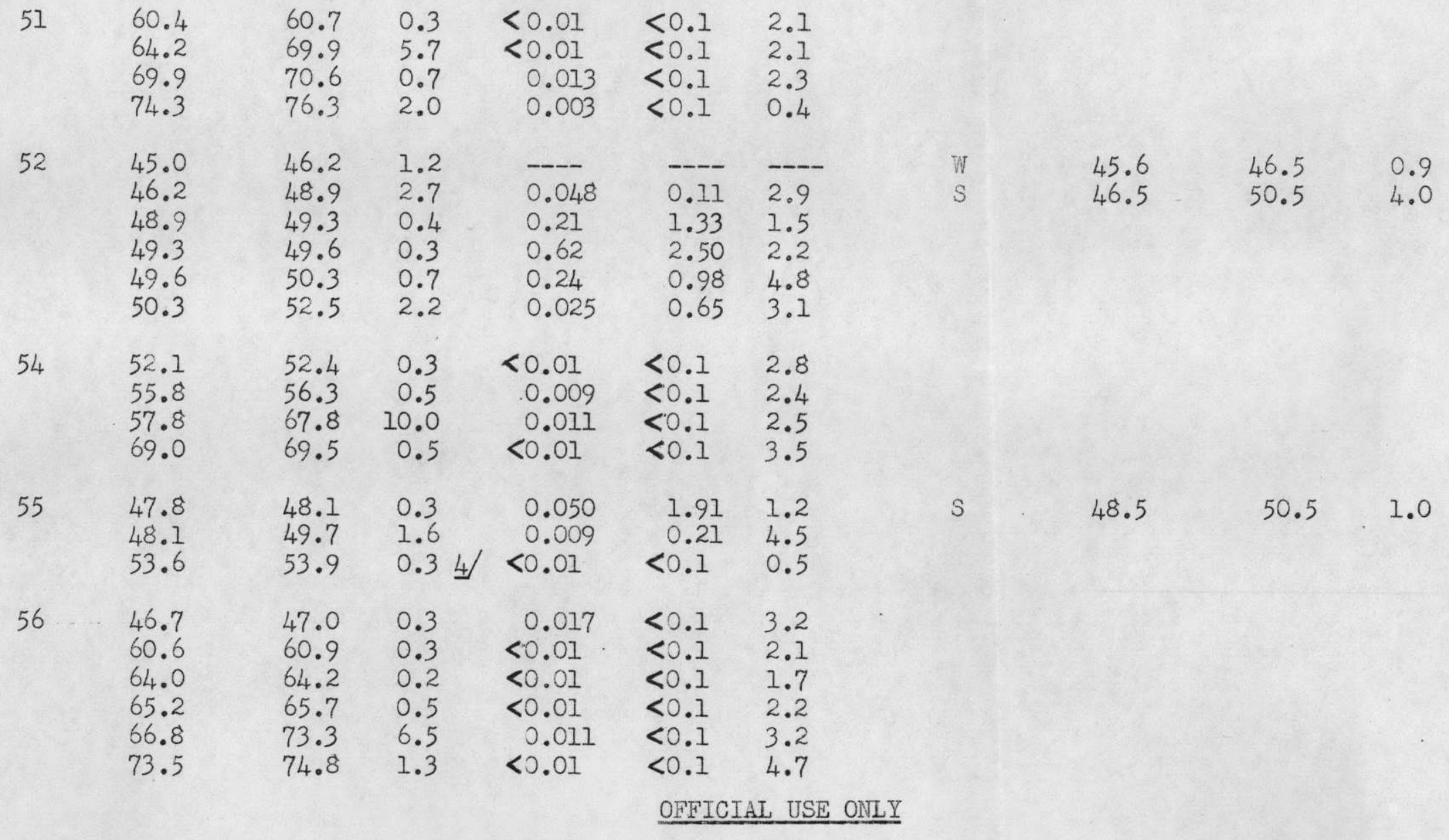




\section{OFFICIAL USE ONLY}

33

Table 3.--Assay and gamma-ray data, Upper group area, San Miguel County, Colorado-Continued

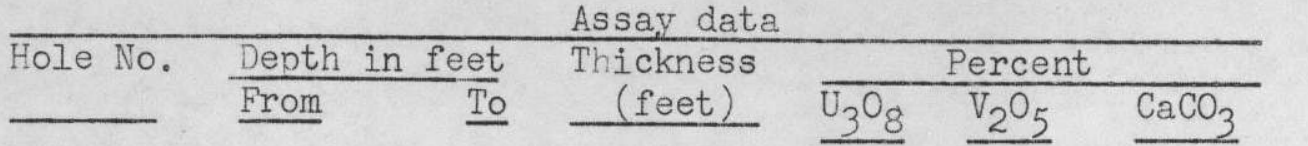

\begin{tabular}{lll}
\multicolumn{3}{c}{ Gamma-ray data } \\
\hline Gamma-ray & Depth in feet & Thickness \\
intensity & From $\quad \underline{\text { To }}$
\end{tabular}

Block I (Big Four, Canyon View, Grant, Sunnyside claims, and public land -- continued)

57

$\begin{array}{lll}31.9 & 33.6 & 1.7 \\ 35.1 & 36.1 & 1.0 \\ 36.4 & 38.9 & 2.5 \\ 39.1 & 40.2 & 1.1 \\ 41.6 & 42.1 & 0.5 \\ 49.7 & 50.2 & 0.5 \\ 55.9 & 56.2 & 0.3\end{array}$

58

$\begin{array}{lll}46.3 & 46.6 & 0.3 \\ 63.3 & 63.8 & 0.5 \\ 66.2 & 66.7 & 0.5 \\ 67.0 & 70.3 & 3.3 \\ 70.8 & 72.5 & 1.7 \\ 72.8 & 73.0 & 0.2 \\ 73.3 & 73.5 & 0.2 \\ 77.0 & 78.3 & 1.3 \\ 78.5 & 79.8 & 1.3 \\ 80.0 & 81.5 & 1.5\end{array}$

$\begin{array}{lr}0.015<0.57 & 2.3 \\ 0.009<0.1 & 2.6 \\ 0.010<0.1 & 3.3 \\ 0.017<0.1 & 4.1 \\ 0.009<0.1 & 12.2 \\ 0.01900 .24 & 3.9 \\ 0.003<0.1 & 4.0\end{array}$

$<0.01<0.1$

$<0.01<0.1$

$<0.01<0.1$

$<0.01<0.1$

$<0.01<0.1$

$<0.01<0.1$

$<0.01<0.1$

$<0.01<0.1$

$<0.01<0.1$

$<0.01<0.1$
W

2.6

3.3

.2

4.0

3.2

2.3

2.5

3.4

3.1

3.8

2.5

2.8

2.9

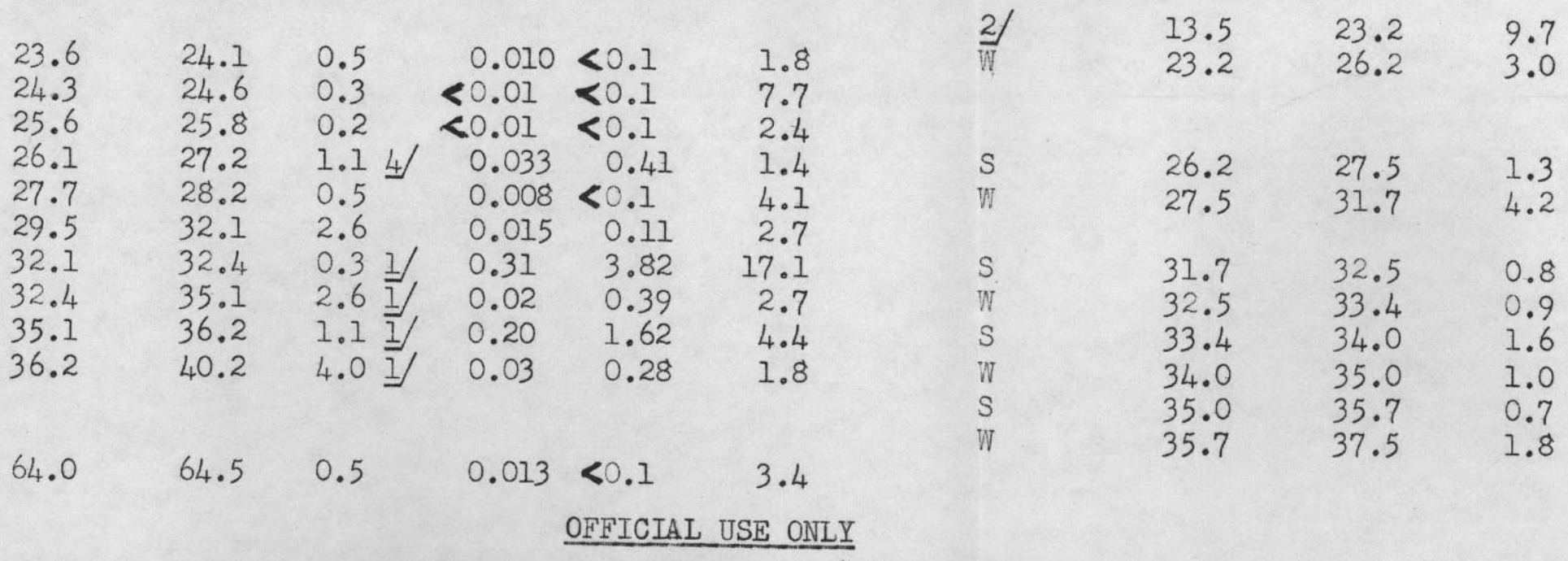


Table 3.--Assay and gamia-ray data, Upper group area, San Miguel County, Colorado-Continued

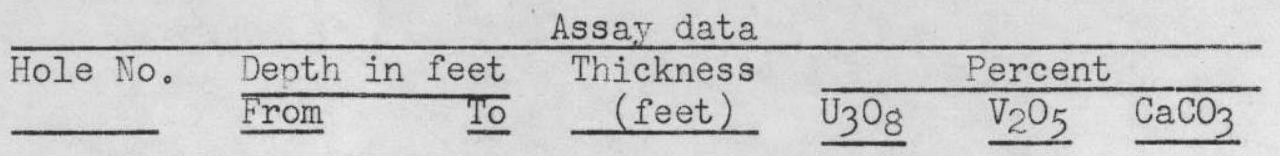

\begin{tabular}{lll} 
& Gamma-ray data & \\
\hline Gamma-ray & Depth in feet & Thickness \\
intensity & From & To
\end{tabular}

Block 1, (Big Four, Canyon View, Grant, Sunnyside claims and public land -- continued)

60

$\begin{array}{ll}13.2 & 13.5 \\ 52.3 & 52.5 \\ 54.0 & 54.8 \\ 56.5 & 56.8 \\ 57.1 & 57.3 \\ 58.1 & 59.3 \\ 60.6 & 61.6 \\ 64.8 & 65.1 \\ 65.6 & 65.8 \\ 66.8 & 67.1 \\ 73.7 & 74.0\end{array}$

61

$\begin{array}{ll}17.9 & 19.7 \\ 19.7 & 21.3 \\ 21.5 & 22.1 \\ 23.2 & 23.8 \\ 24.1 & 24.6 \\ 29.2 & 29.5 \\ 31.3 & 32.5 \\ 35.2 & 36.6 \\ 40.7 & 41.0 \\ 42.0 & 43.0 \\ 43.7 & 45.4 \\ 60.3 & 60.8 \\ 74.6 & 75.1\end{array}$

$\begin{array}{lc}0.34 & 0.003 \\ 0.2 & <0.01 \\ 0.8 & 0.018 \\ 0.3 & <0.01 \\ 0.2 & <0.01 \\ 1.2 & <0.01 \\ 1.0 & <0.01 \\ 0.3 & <0.01 \\ 0.2 & <0.01 \\ 0.3 & <0.01 \\ 0.3 & 0.021\end{array}$

0.05

$<0.05$

1.2

undet.

undet.

undet.

undet.

undet.

undet.

undet.

undet.

undet.

$\begin{array}{lllll}1.8 & 4 & 0.10 & 0.71 & 2.7\end{array}$

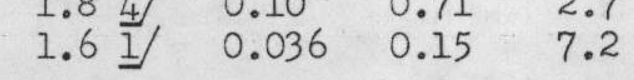

$0.6<0.01 \quad 0.07$ undet.

$\begin{array}{cccc}0.6 & <0.01 & 0.07 & \text { undet. } \\ 0.5 & 0.009 & 0.11 & 2.7\end{array}$

$\begin{array}{llll}0.5 & 0.009 & 0.11 & 2.7 \\ 0.3 & <0.01 & <0.05 & \text { undet. } \\ 1.2 & <0.01 & 0.14 & \text { undet. }\end{array}$

1.2 1. $<0.01<0.14 \quad 0.14$ undet.

$0.3<0.01 \quad 0.09$ undet.

$\begin{array}{llll}1.0 & 0.023 & 0.17 & 11.9\end{array}$

$\begin{array}{lll}1.7 & 0.015<0.05 \quad 6.4\end{array}$

$\begin{array}{llll}0.5 & 0.021 & 0.11 & 2.3\end{array}$

$\begin{array}{llll}0.53 / & 0.029 & 0.08 & 11.1\end{array}$

OFFICIAL USE ONLY

$\begin{array}{llll}S & 18.5 & 19.5 & 1.0 \\ W & 19.5 & 20.5 & 1.0 \\ S & 20.5 & 20.8 & 0.3\end{array}$




\section{OFFICIAL USE ONLY}

Table 3.--Assay and gamna-ray data, Upper group area, San Miguel County, Colorado--.-Continued

\begin{tabular}{|c|c|c|c|}
\hline Hole No. & in feet & Thickness & Percent \\
\hline & From & (feet) & $\mathrm{V}_{2} \mathrm{O}_{5} \quad \mathrm{CaCO}_{3}$ \\
\hline
\end{tabular}

\begin{tabular}{lll}
\multicolumn{3}{c}{ Gamma-ray data } \\
\hline Gamma-ray & Depth in feet & \\
intensity & From & (feet)
\end{tabular}

Block 1, (Big Four, Canyon View, Grant, Sunnyside claims and public land -continued)

62

$\begin{array}{ll}66.4 & 67 \\ 68.2 & 68 \\ 69.4 & 69 \\ 89.7 & 90 \\ 96.5 & 97\end{array}$

63

$\begin{array}{ll}86.3 & 86.5 \\ 87.6 & 88.1 \\ 88.6 & 89.8\end{array}$

88.6

57.3

64

$\begin{array}{ll}65 \quad & 17.6 \\ 61.3\end{array}$

66

67.2
68.9
69.7
90.9
97.0

0.8
0.7
0.3
1.2
0.5

$<0.01$
0.017

$<0.05$

0.22

undet. 2.1

$<0.01 \quad 0.08$

$<0.01$

$<0.05$

undet. undet.

4.5

$0.2 \quad 0.033<0.05$

$0.5 \quad 0.021<0.05$

$1.2<0.01<0.05$

$0.016<0.05$

5.2

2.2

undet.

2.9

57.6

0.3

$0.002<0.05$

2.1

18.5
63.4

$0.94 / 0.004<0.05$

$\begin{array}{ll}0.004 & <0.05 \\ <0.01<0.05\end{array}$

3.7

undet.

i0.8 13.1

$24.5 \quad 24.9$

$26.3 \quad 26.7$

2.3

0.4

0.012

0.013

0.07

$<0.05$

$0.018 \quad 0.10$

$<0.01$

$<0.05$

$30.3 \quad 30.8$

$31.0 \quad 31.3$

$\begin{array}{ll}31.5 & 32.5 \\ 32.5 & 34.0\end{array}$

$34.9 \quad 35.1$

$88.4 \quad 88.6$

91.7

92.1

0.5

0.3

1.0

0.013

$<0.01$

$<0.01$

0.019

$\begin{array}{llll}0.2 & <0.01<0.05 & < & <0 \\ 0.4 & <0.01 & <0.05 & \text { undet. }\end{array}$

9.5

0.9

1.0

undet.

4.9

undet.

undet.

undet.

18.7

$0.4<0.01<0.05$ undet.

OFFICIAL USE ONLY
Barren

Barren

: 


\section{OFICIAL USE ONLY}

Table 3.--Assay and gamma-ray data, Upper group area, San Miguel County, Culorado-Continued

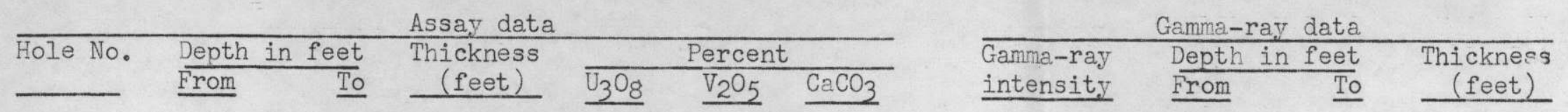

Block I (Big Four, Canyon View, Grant, Sunnyside clairs, and public land - continued)

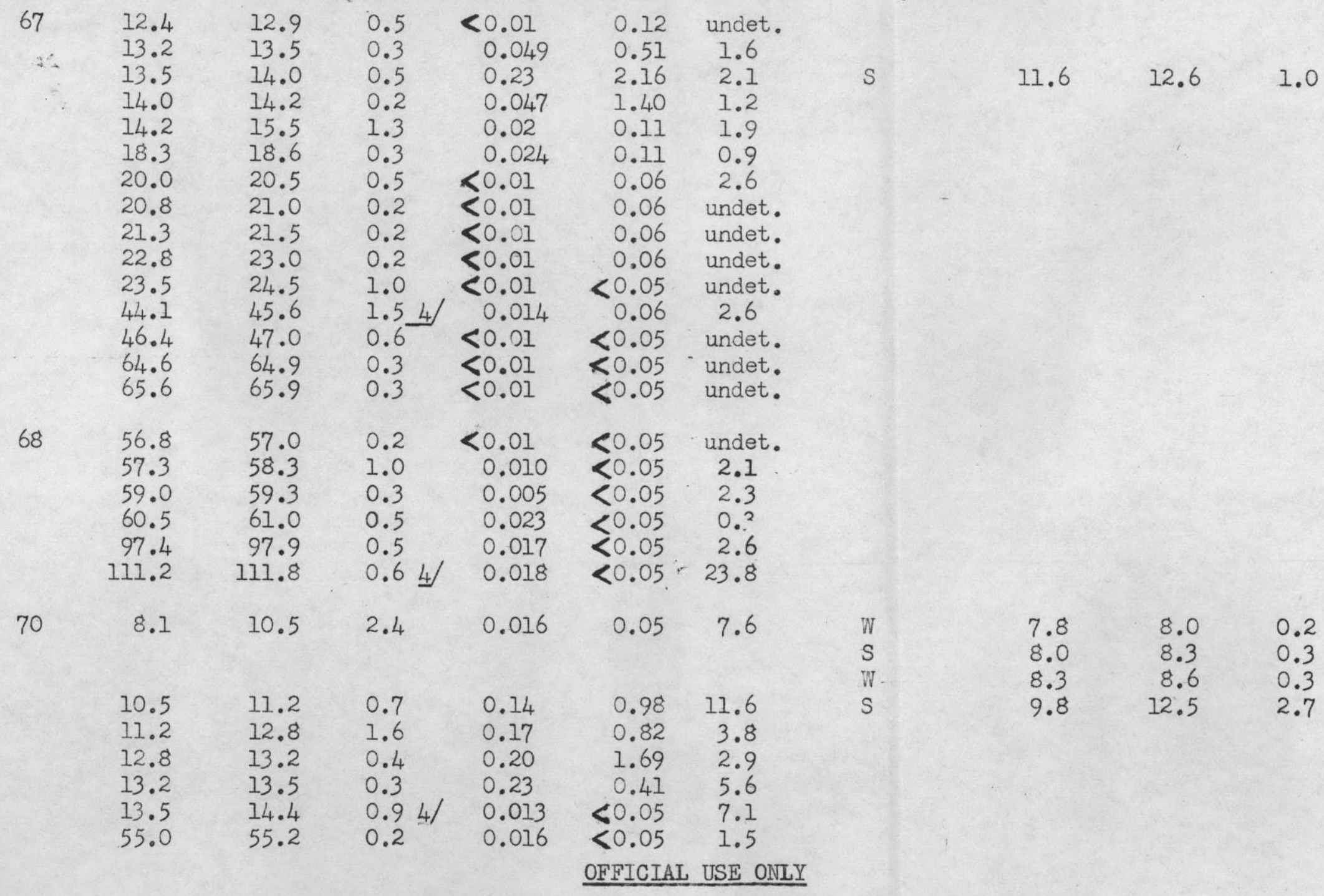


JFFICIAL USE QNLY

37

Table 3.--Assay and gamma-ray data, Upper grup area, san Miguel County, Colorado-m Continued

\begin{tabular}{|c|c|c|c|c|c|c|c|}
\hline \multirow{2}{*}{ Hole No. } & & Assay data & \multicolumn{2}{|c|}{ Percent } & \multicolumn{3}{|c|}{ Gamma-ray data } \\
\hline & $\frac{\text { Depth in feet }}{\text { Fron }}$ & $\begin{array}{l}\text { Thickness } \\
\text { (Feet) }\end{array}$ & $\overline{\mathrm{U}_{3} \mathrm{O}_{8}}$ & $\mathrm{CaCO}_{3}$ & $\begin{array}{l}\text { Gamma-ray } \\
\text { intensity }\end{array}$ & $\frac{\text { Depth in feet }}{\text { From }}$ & $\begin{array}{l}\text { Thickness } \\
\text { (feet) }\end{array}$ \\
\hline
\end{tabular}

Block 1 (Big Four, Canyon View, Grant, Sunnyside claims, and public land - continued)

71

$\begin{array}{rr}2.0 & 4.0 \\ 28.6 & 30.1 \\ 35.1 & 35.6 \\ 36.6 & 37.1 \\ 37.6 & 39.3 \\ 39.8 & 40.0 \\ 54.4 & 54.9 \\ 56.9 & 57.4\end{array}$

72

$\begin{array}{llll}19.4 & 19.7 & 0.3 & 0.14 \\ 19.7 & 21.0 & 1.3 & 0.039 \\ & & & \\ & & & \\ 24.8 & 25.1 & 0.3 & 0.006 \\ 25.3 & 27.0 & 1.7 & 0.031 \\ 33.4 & 34.2 & 0.8 & 0.019 \\ 34.2 & 37.0 & 2.5 & 0.024 \\ & & & \\ 37.3 & 37.5 & 0.2 & 0.029 \\ 39.1 & 39.9 & 0.84 & 0.034 \\ 50.6 & 51.1 & 0.5 & <0.01 \\ 67.1 & 67.8 & 0.74 & 0.027\end{array}$

\begin{tabular}{|c|c|c|}
\hline $\begin{array}{l}2.01 / \\
1.5 \\
0.5 \\
0.5 \\
1.7 \\
0.2 \quad 4 / \\
0.7\end{array}$ & $\begin{array}{c}0.045 \\
0.018 \\
<0.01 \\
0.019 \\
0.02 \\
<0.01 \\
0.018 \\
0.013\end{array}$ & $\begin{array}{r}0.33 \\
0.09 \\
0.22 \\
0.19 \\
0.09 \\
0.18 \\
<0.05 \\
<0.05\end{array}$ \\
\hline
\end{tabular}

$0.13 \quad 5.1$

$0.07 \quad 4.6$

$<0.05 \quad 16.6$

$<0.05 \quad 11.0$

$0.06 \quad 4.1$

$\begin{array}{ll}0.06 & 2.4\end{array}$

$\begin{array}{rr}0.06 & 3.4 \\ 0.05 & 6.5\end{array}$

$<0.05 \quad 6.5$

11.1

$\begin{array}{lll}17.3 & 17.9 & 0.6 \\ 17.9 & 18.3 & 0.4 \\ 18.3 & 19.8 & 1.5 \\ 19.8 & 20.2 & 0.4 \\ 21.2 & 21.4 & 0.2 \\ 21.4 & 22.4 & 1.0\end{array}$

$\begin{array}{lll}34.8 & 35.3 & 0.5\end{array}$

$\begin{array}{lll}35.3 & 35.7 & 0.4\end{array}$

$\begin{array}{lll}35.7 & 35.9 & 0.2\end{array}$

$\begin{array}{lll}38.8 & 39.3 & 0.5\end{array}$

OFFICIAL USE ONLY 
$\frac{\text { OFFICIAL USE ONLY }}{38}$

Lable 3.--Assay and gamma-ray data, Upper group area, San Miguel County, Colorado--Continued

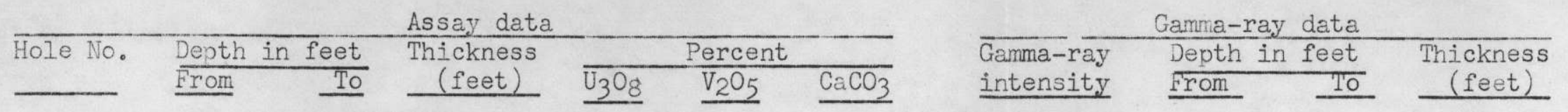

Block 1 (Big Four, Canyon View, Grant, Sunnyside claims, and public land -- continued)

73

74

$$
\begin{aligned}
& 54.1 \\
& 55.4
\end{aligned}
$$

55.1
56.1

1.0
0.7

$27.8 \quad 1.1 \%$

26.7

34.4

36.8

37.8

38.0

2.4

$38.0 \quad 0.2$

40.9

2.9

40.9

$43.4 \quad 2.5$

44.8

45.6

47.8

45.3

$47.3 \quad 0.5$

$\begin{array}{ll}48.1 & 0.3\end{array}$

40.9

41.2
49.8

0.4

40.9

49.5

65.2

66.

0.3

66.31 .14

76

\section{$\begin{array}{ll}15.8 & 0.6\end{array}$}

$\begin{array}{ll}16.2 & 0.4\end{array}$

16.6

17.1

$\begin{array}{ll}21.3 & 1.2 \\ 25.5 & 0.2\end{array}$

$26.5 \quad 0.7$
0.014

0.034

$<0.05$

$<0.05$

2.4
2.9

0.005

0.019

0.067

0.21

0.05
0.12

9.4
3.9

$0.36 \quad 5.1$

$\begin{array}{ll}1.25 & 2.0\end{array}$

0.061

0.76

0.015

0.45

3.0

0.003

0.019

0.013

0.05

$<0.05$

3.0

$<0.05 \quad 3.1$

0.13

0.066

3.42

0.3

0.006

0.010

2.26
0.10

0.10
$<0.05$

0.8

0.4

0.041

0.22

0.28

0.20

0.045

$<0.01$

0.025

0.009
$0.19 \quad 2.0$

$1.44 \quad 14.7$

$\begin{array}{ll}1.64 & 7.7\end{array}$

$1.13 \quad 2.6$

$0.41 \quad 4.2$

0.05 undet.

$0.07 \quad 1.6$

$0.06 \quad 4.4$

OFFICIAL USE ONLY
$34.9 \quad 35.9 \quad 1.0$

$\begin{array}{lll}35.9 & 37.1 & 1.2\end{array}$

$\begin{array}{lll}37.1 & 39.1 & 2.0\end{array}$

$\begin{array}{lll}40.4 & 40.8 & 0.4\end{array}$

$\begin{array}{lll}41.7 & 42.0 & 0.3\end{array}$

$\begin{array}{lll}43.4 & 43.7 & 0.3\end{array}$

$\begin{array}{lll}45.0 & 45.7 & 0.7\end{array}$

$\begin{array}{lll}39.2 & 39.9 & 0.7\end{array}$

$\begin{array}{lll}15.8 & 17.2 & 1.4\end{array}$

$\begin{array}{lll}18.6 & 19.8 & 1.2\end{array}$ 


\section{OFFICIAL USE ONLY}

\section{9.}

Table 3.--Assay and gamna-ray data, Upper group area, San Miguel County, Colorado--Continued

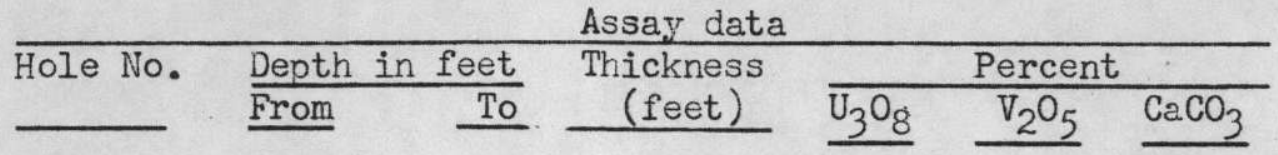

\begin{tabular}{lll} 
& Garma-ray data \\
\hline Gamma-ray & Depth in feet & Thickness \\
intensity & From $\quad$ To & (feet)
\end{tabular}

Block 1 (Big Four, Canyon View, Grant, Sunnyside claims, and public land -- continued)

77

16.1
16.4
16.6
60.5

16.4
16.6
17.7
62.2

0.3

0.2

1.1

0.005

0.005

0.015

0.007

78

42.1
46.0
47.3
48.8
58.1
59.3
66.4
69.4
71.1
73.4

79

$\begin{array}{llc}43.4 & 1.3 & 0.015 \\ 46.5 & 0.5 & <0.01 \\ 48.0 & 0.7 & 0.016 \\ 49.5 & 0.7 & <0.01 \\ 58.8 & 0.7 & <0.01 \\ 60.0 & 0.7 & <0.01 \\ 69.4 & 3.0 & <0.01 \\ 70.6 & 1.2 & <0.01 \\ 71.7 & 0.6 & <0.01\end{array}$

$\begin{array}{ll}1.72 & 1.0 \\ 2.18 & 1.0 \\ 0.81 & 2.5 \\ 0.05 & 8.4\end{array}$

$<0.05$

$<0.05$ undet.

< $0.05 \quad 4.6$

$<0.05$ undet.

$<0.05$ undet.

c.0.05 undet

$<0.05$ undet.

$<0.05$ undet.

0.05 undet

$<0.05 \quad 5.6$

$\begin{array}{llll}21.4 & 22.4 & 1.0 & 0.032 \\ 22.4 & 22.5 & 0.1 & 0.12 \\ 22.5 & 22.8 & 0.3 & 0.73 \\ 22.8 & 23.0 & 0.2 & 1.56 \\ 23.0 & 23.3 & 0.3 & 0.59 \\ 23.3 & 23.5 & 0.2 & 0.041 \\ 23.5 & 25.0 & 1.5 & 0.016\end{array}$

$\begin{array}{rr}0.22 & 0.3 \\ 0.58 & 0.1 \\ 1.06 & 13.9 \\ 4.99 & 1.4 \\ 3.44 & 1.7 \\ 4.30 & 1.0 \\ 0.78 & 11.6\end{array}$

OFFICIAL USE ONLY
W

16.51

17.1

0.6

*

$\begin{array}{llll}\text { VS } & 21.8 & 22.4 & 0.6 \\ \text { W } & 22.4 & 23.6 & 1.2\end{array}$


OFFIGTAC USE ONLY

Table 3.--Assay and gamma-ray data, Upper group area, San M1guel County, Colorado-Continued

\begin{tabular}{|c|c|c|c|}
\hline Hole No. & Depth in feet & Thickness & Percent \\
\hline & From & (feet) & $\mathrm{CaCO}_{3}$ \\
\hline
\end{tabular}

\begin{tabular}{lll}
\multicolumn{3}{c}{ Gamma-ray data } \\
\hline Gamma-ray & Depth in feet & Thickness \\
intensity & From $\quad$ To & (feet)
\end{tabular}

Block I (Big Four, Canyon View, Grant, Sunnyside claims and public land -- continued)

80

5.5
7.4
7.7
8.1
8.6
8.9
9.1
9.3
10.5
10.8
11.3
11.4
13.7

7.4
7.7
8.1
8.6
8.9
9.1
9.3
10.1
10.8
11.3
11.4
13.7
15.0

81

24.3
24.5
24.9
26.0
27.5
27.7
47.6

24.5

24.9

25.8

27.5

27.7

29.9

43.0

82

$\begin{array}{rr}2.7 & 3.1 \\ 13.8 & 14.8 \\ 39.7 & 40.2 \\ 40.5 & 41.0\end{array}$

1.9
0.3
0.4
0.5
0.3
0.2
0.2
0.8
0.3
0.5
0.1
2.3
$1.3 \quad 4$

\subsection{3}

0.59

0.071

0.008

0.077

0.35

0.48

0.46

0.31

0.44

0.13

0.064

0.015

0.2

0.94

1.54

0.2

2.2

1.4

0.015

0.13

0.024

0.008

0.073

0.04

0.017

0.17

$4.12 \quad 2.3$

$0.27 \quad 2.0$

$0.11 \quad 12.7$

0.1530 .0

$3.1 \quad 9.6$

$2.21 \quad 12.8$

$\begin{array}{ll}1.93 & 7.1\end{array}$

$3.93 \quad 1.0$

$2.06 \quad 0.3$

$0.31 \quad 2.5$

$<0.05 \quad 8.9$

$<0.05 \quad 8.9$

$0.32 \quad 2.1$

$0.11 \quad 0.7$

$0.08 \quad 5.6$

$0.19 \quad 9.7$

$0.14 \quad 4.0$

$0.05 \quad 4.7$

$\begin{array}{llll}0.4 & 0.047<0.05 \quad 4.8\end{array}$

$\begin{array}{rrrr}0.4 & 0.047 & <0.05 & 4.8 \\ 1.0 & 0.014 & 0.05 & 3.3\end{array}$

0.44

0.44

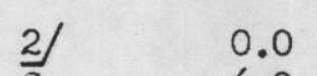

0.0
6.0

6.0

6.7

7.4

S

$<0.05$ undet.

V

S 23

23.3

S

26.1

25.7

$\begin{array}{llll}W & 10.2 & 12.3 & 1.1 \\ S & 12.3 & 13.2 & 0.9\end{array}$

$23.8 \quad 0.5$

27.9

1.9

OFFICIAL USE ONLY 


\section{OFFICIAL USE ONLY}

Table 3.-Assay and gamma-ray data, Upper group area, san Miguel County, Colorado--Continued

\begin{tabular}{|c|c|c|c|c|c|c|c|}
\hline \multirow[b]{2}{*}{ Hole No. } & \multicolumn{4}{|c|}{$\frac{\text { Assay data }}{\text { Thickness }}$} & \multicolumn{3}{|c|}{ Gamma-ray data } \\
\hline & $\begin{array}{l}\text { Depth in feet } \\
\text { From }\end{array}$ & $\begin{array}{l}\text { Thickness } \\
\text { (feet) }\end{array}$ & $\frac{\text { Percent }}{\mathrm{V}_{2} \mathrm{O}_{5}}$ & $\mathrm{CaCO}_{3}$ & $\begin{array}{l}\text { Gamma-ray } \\
\text { intensity }\end{array}$ & $\frac{\text { Depth in feet }}{\text { From }}$ & $\begin{array}{l}\text { Thickness } \\
\text { (feet) }\end{array}$ \\
\hline
\end{tabular}

Block 1 (Big Four, Canyon View, Grant and Sunnyside claims, and public land - continued)

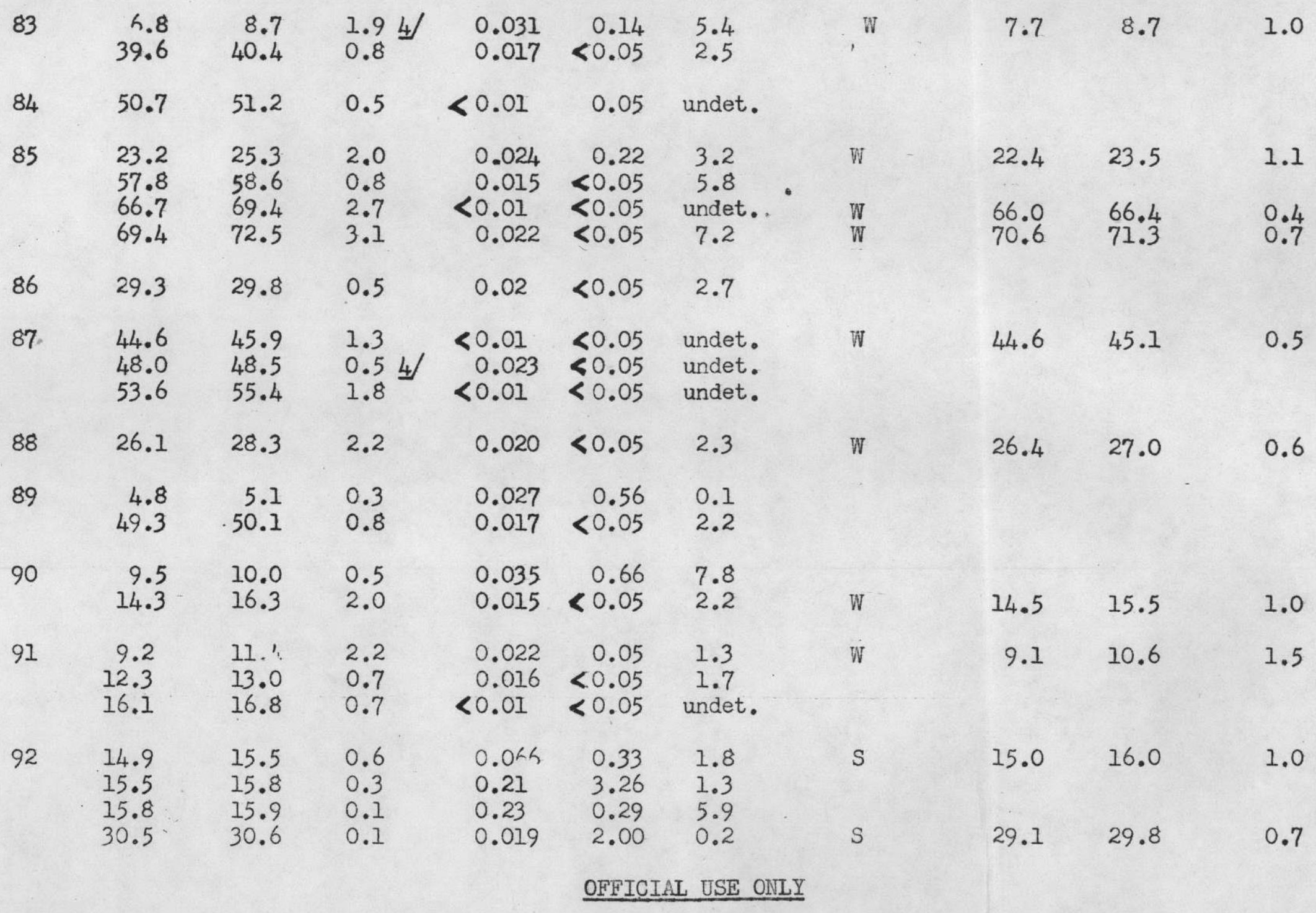




\section{OFFICIAL USE ONLY}

42

Table 3.--Assay and gamma-ray data, Upper group area, San Miguel County, Colorado--Continued

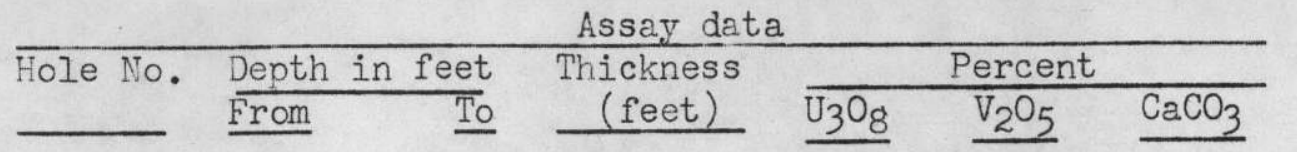

\begin{tabular}{lll} 
& Gamma-ray data \\
\hline Gamma-ray & Depth in feet Thickness \\
intensity & From (feet)
\end{tabular}

Block I (Big Four, Canyon View, Grant and Sunnyside claims, and public land -- continued)

93

$$
\begin{aligned}
& 54.6 \\
& 64.0 \\
& 67.0 \\
& 72.6
\end{aligned}
$$

$$
\begin{aligned}
& 54.8 \\
& 67.0
\end{aligned}
$$$$
69.2
$$$$
\begin{aligned}
& 0 . \\
& 3 . \\
& 2 . \\
& 2 .
\end{aligned}
$$$$
\begin{aligned}
& 0.24 \\
& 3.0 \\
& 2.2 \\
& 2.8
\end{aligned}
$$

46.7
62.7

1.0
0.3

62.4$$
2.3
$$

2.2
3.5

3.5
3.8

6.8

7.1

9.1

10.8

14.7

17.1

19.0

20.6

$$
\begin{aligned}
& 0.8 \\
& 0.6 \\
& 0.3
\end{aligned}
$$

3.0

0.3

2.0

$$
0.3
$$$$
2.0
$$$$
0.7
$$$$
0.5
$$$$
\begin{aligned}
& 0.5 \\
& 0.5
\end{aligned}
$$

$<.005$
$<0.01$
$<0.01$

0.08

0.05

$0.028<0.05$

0.5
undet
undet.

undet
9.0

$\begin{array}{lll}0.012 & 0.08 & 0.5\end{array}$

$<0.01$

$<0.05$

$\begin{array}{ccc}0.014 & 0.14 & 1.8 \\ 0.022 & 0.21 & 1.7 \\ 0.035 & 0.45 & 1.0 \\ 0.017 & 0.15 & 2.5 \\ 0.025 & 0.70 & 2.0 \\ 0.020 & 0.20 & 5.3 \\ <0.01 & 0.17 & \text { undet. } \\ 0.017 & 0.14 & 2.5 \\ 0.01 & 0.08 & \text { undet. } \\ 0.014 & 0.06 & 3.4 \\ 0.012 & 0.06 & 2.7\end{array}$

96

15.0

15.0
22.9

28.1

31.6

59.2

59.9

60.9

63.3

20.0

23.9

5.01

3.0
1.0
1.0

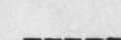

0.014
0.015

$<0.05 \quad--12.3$

32.3

59.7

60.7

0.7

0.032

$\begin{array}{lll}0.012 & 0.05 & 1.9\end{array}$

$<0.01$

99

49.3
0.013

63.8

49.6

0.3

$<0.01$
W

undet.

0.11

0.25

0.06

undet.

0.06 undet.

71.2

71.6

0.4

W

3.3

4.0

0.7

W

4.9

9.1

$4 \cdot 2$

$<0.05$ undet.

51.4

51.8

0.4
0.5 


\section{OFFICTAL USE ONLY}

43

Table 3.--Assay and gamma-ray data, Upper group area, San Miguel County, Colorado--Continued

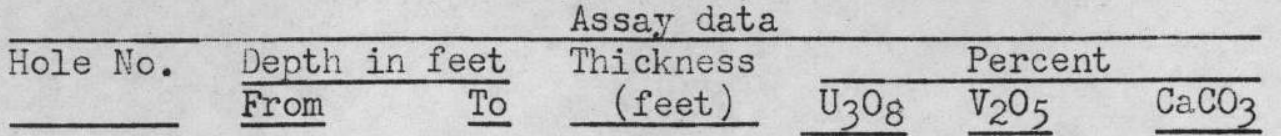

$\begin{array}{lll}\text { Gamma-ray } & \text { Depth in feet } & \text { Thickness } \\ \text { intensity } & \text { From }\end{array}$

Block 1 (Big Four, Canyon View, Grant and Sunnyside claims, and public land -- continued)

\begin{tabular}{|c|c|c|c|c|c|c|c|c|}
\hline $\begin{array}{l}4.6 \\
5.0 \\
5.7 \\
6.0 \\
8.4\end{array}$ & $\begin{array}{l}4.8 \\
5.7 \\
6.0 \\
7.5 \\
8.9\end{array}$ & $\begin{array}{l}0.2 \\
0.7 \\
0.3 \\
1.5 \\
0.5\end{array}$ & $\begin{array}{l}0.005 \\
1.58 \\
0.34 \\
0.089 \\
0.021\end{array}$ & $\begin{array}{c}<0.1 \\
5.09 \\
0.60 \\
0.39 \\
0.16\end{array}$ & $\begin{array}{l}3.0 \\
0.2 \\
0.2 \\
0.7 \\
0.1\end{array}$ & $\begin{array}{l}\text { 2f } \\
\text { vs } \\
s\end{array}$ & $\begin{array}{l}0.0 \\
4.1 \\
5.1\end{array}$ & $\begin{array}{l}4.1 \\
5.1 \\
7.1\end{array}$ \\
\hline $\begin{array}{r}0.0 \\
40.0\end{array}$ & $\begin{array}{l}20.0 \\
40.2\end{array}$ & $\begin{array}{c}20.0 \\
0.2\end{array}$ & $\overline{0.34}$ & $\overline{2.90}$ & $<\overline{0.1}$ & $\begin{array}{l}w \\
w\end{array}$ & $\begin{array}{r}0.0 \\
39.2\end{array}$ & $\begin{array}{l}18.0 \\
40.0\end{array}$ \\
\hline $\begin{array}{l}13.3 \\
26.0 \\
37.3\end{array}$ & $\begin{array}{l}14.1 \\
28.5 \\
38.4\end{array}$ & $\begin{array}{l}0.84 \\
2.5 \\
1.1\end{array}$ & $\begin{array}{l}0.02 \\
0.025 \\
0.021\end{array}$ & $\begin{array}{l}0.23 \\
0.20 \\
0.16\end{array}$ & $\begin{array}{l}1.1 \\
2.3 \\
1.2\end{array}$ & $\begin{array}{l}W \\
W \\
W\end{array}$ & $\begin{array}{l}12.3 \\
24.7 \\
35.4\end{array}$ & $\begin{array}{l}13.6 \\
25.8 \\
36.0\end{array}$ \\
\hline $\begin{array}{l}19.2 \\
20.3 \\
20.8 \\
21.0 \\
21.4 \\
23.6 \\
24.5 \\
25.1 \\
25.4 \\
26.6 \\
26.8 \\
27.6 \\
60.0\end{array}$ & $\begin{array}{l}20.3 \\
20.8 \\
21.0 \\
21.4 \\
23.6 \\
24.5 \\
25.1 \\
25.4 \\
26.6 \\
26.8 \\
27.6 \\
29.8 \\
60.7\end{array}$ & $\begin{array}{l}1.1 \\
0.5 \\
0.2 \\
0.4 \\
2.2 \\
0.9 \\
0.6 \\
0.3 \\
1.2 \\
0.2 \\
0.8 \\
2.2 \\
0.7\end{array}$ & $\begin{array}{l}0.026 \\
0.091 \\
0.24 \\
0.090 \\
0.025 \\
0.14 \\
0.99 \\
0.058 \\
0.066 \\
0.094 \\
0.093 \\
0.015 \\
0.020\end{array}$ & $\begin{array}{r}<0.1 \\
3.44 \\
1.80 \\
1.88 \\
0.14 \\
2.62 \\
3.81 \\
0.71 \\
1.05 \\
0.88 \\
0.35 \\
<0.1 \\
<0.1\end{array}$ & $\begin{array}{l}1.9 \\
0.7 \\
1.8 \\
0.6 \\
1.8 \\
0.7 \\
0.3 \\
1.9 \\
1.6 \\
1.8 \\
2.3 \\
2.7 \\
0.9\end{array}$ & Not & & \\
\hline 47.0 & 50.0 & 3.04 & 0.002 & $\begin{array}{r}0.22 \\
\text { OFFIC } \\
\end{array}$ & $\begin{array}{r}3.2 \\
\text { L USE } \\
\end{array}$ & $W$ & 47.8 & 48.8 \\
\hline
\end{tabular}




\section{OFFICIAL USE ONLY}

Table 3.--Assay and gamma-ray data, Upper group area, San Miguel County, Colorado--Continued

Assay data
Hole No. Depth in feet Thickness $\frac{\text { Percent }}{\text { (feet) }} \frac{\mathrm{U}_{3} \mathrm{O}_{8}}{\mathrm{~V}_{2} \mathrm{O}_{5}} \mathrm{CaCO}_{3}$

Block I (Big Four, Canyon View, Grant, Sunnyside claims, and public land-continued)

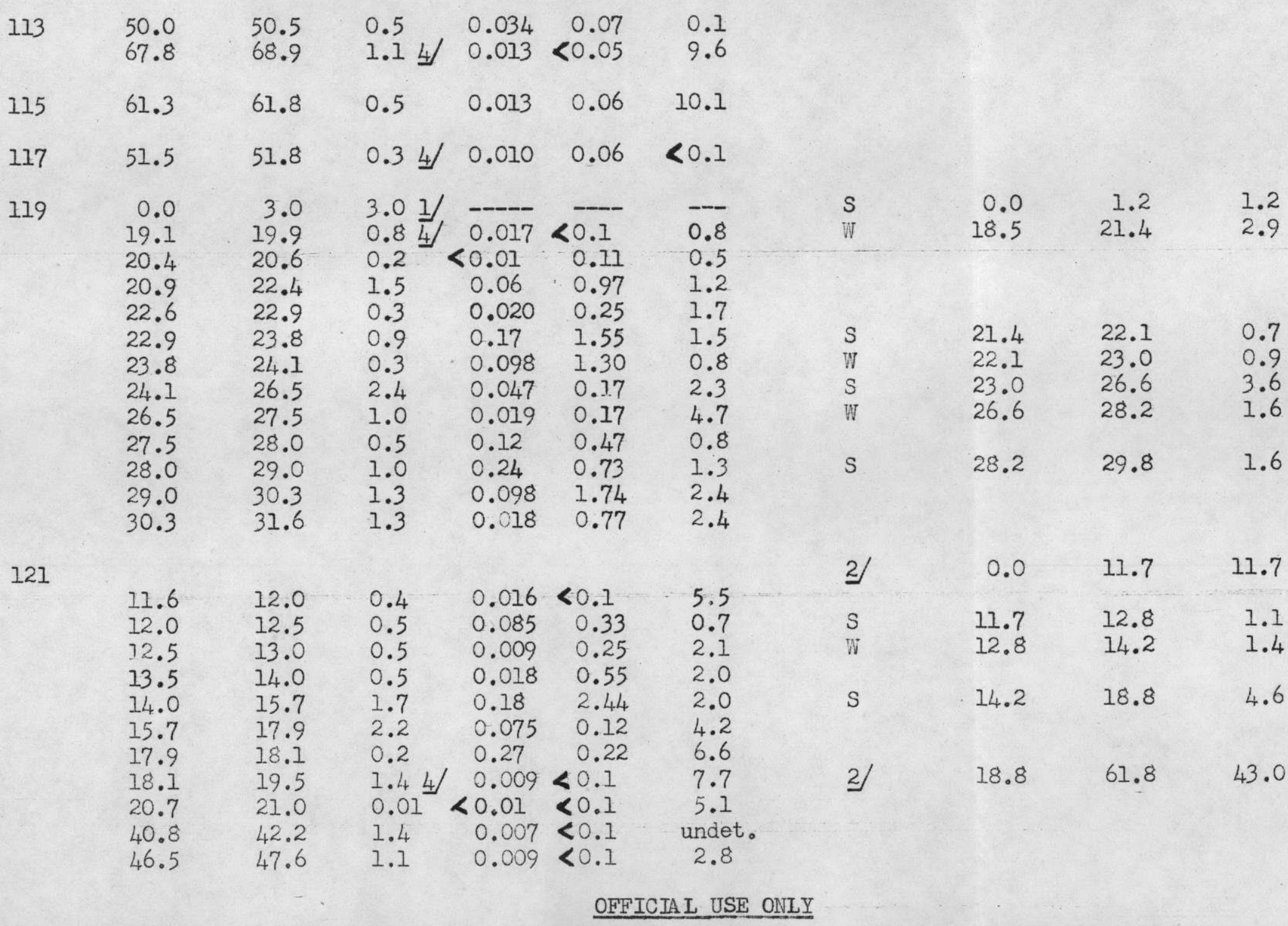




\section{OFFICIAL USE ONLY}

45

Table 3.--Assay and gamna-ray data, Upper group area, San Miguel County, Colorado--Continued

\begin{tabular}{|c|c|c|c|c|c|c|}
\hline \multirow[b]{2}{*}{ Hole No. } & \multicolumn{3}{|c|}{ Assay data } & \multicolumn{3}{|c|}{ Gamma-ray data } \\
\hline & $\frac{\text { Depth in feet }}{\text { From To }}$ & $\begin{array}{c}\text { Thickness } \\
\text { (feet) }\end{array}$ & $\frac{\text { Percent }}{\mathrm{V}_{2} \mathrm{O}_{5} \mathrm{CaCO}_{3}}$ & $\begin{array}{l}\text { Gamma-ray } \\
\text { intensity }\end{array}$ & $\frac{\text { Depth in feet }}{\text { From }}$ & $\begin{array}{c}\text { Thickness } \\
\text { (feet) }\end{array}$ \\
\hline
\end{tabular}

Block I (Big Four, Canyon View, Grant, Sunnyside claims, and public land -- continued)

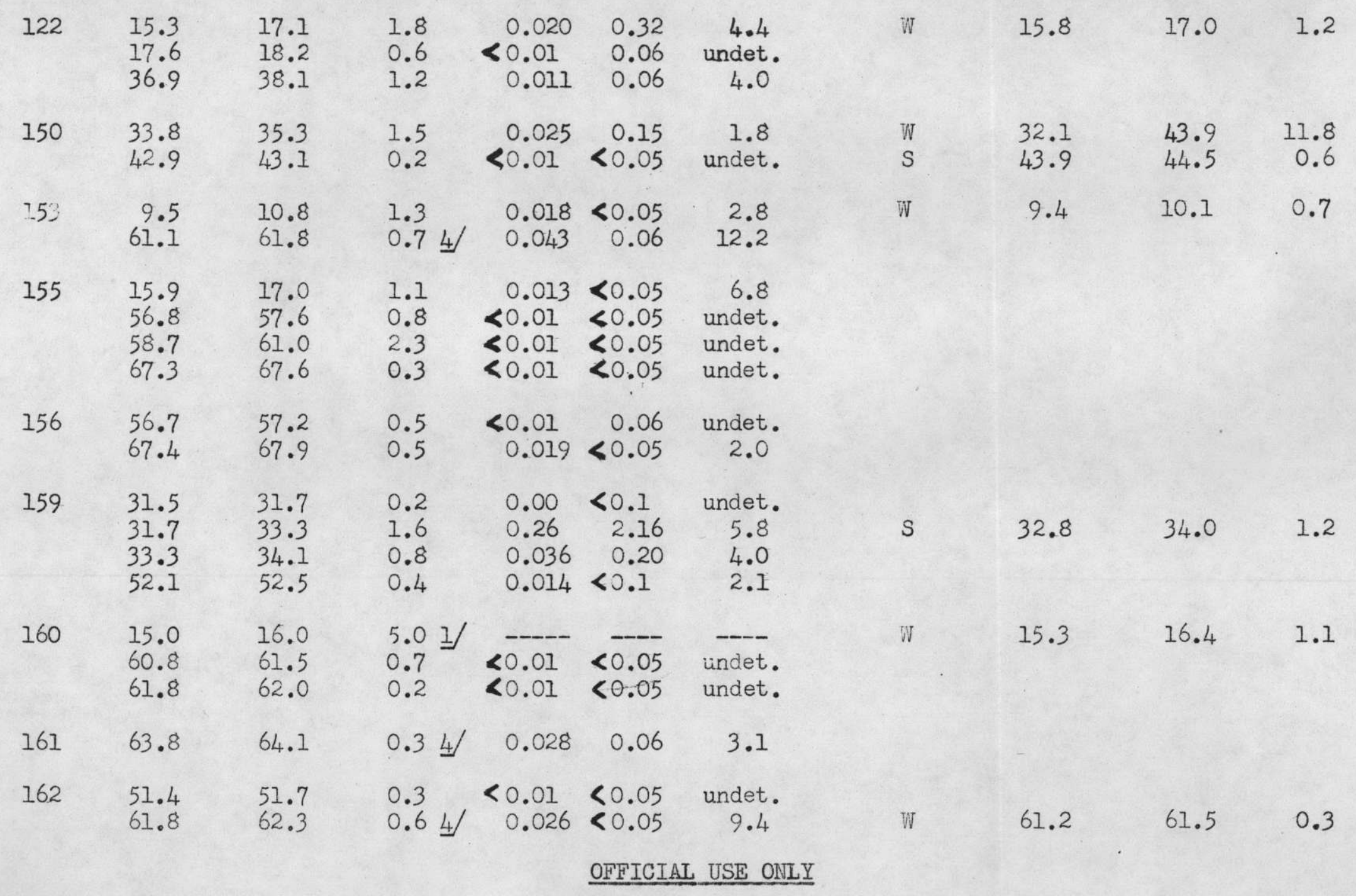




\section{OFFICIAL USE ONLY}

\section{6}

Table 3.--Assay and gamna-ray data, Upper group area, San Miguiel County, Colorado--Continued

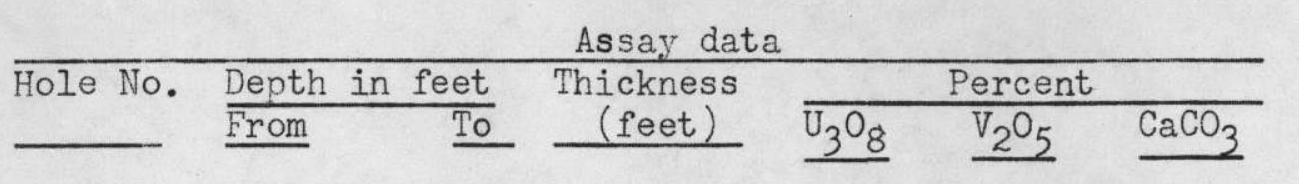

\begin{tabular}{lll} 
& Gamma-ray data & \\
\hline Gamma-ray & Depth in feet & Thickness \\
intensity & From $\quad$ To &
\end{tabular}

Block I (Big Four, Canyon View, Grant, Sunnyside claims, and public land -- continued)

\begin{tabular}{|c|c|c|c|c|c|c|c|c|c|c|}
\hline 164 & $\begin{array}{l}43.5 \\
60.0\end{array}$ & $\begin{array}{l}44.1 \\
60.5\end{array}$ & $\begin{array}{l}0.6 \\
0.5\end{array}$ & $\begin{array}{l}<0.01 \\
<0.01\end{array}$ & $\begin{array}{r}0.08 \\
<0.05\end{array}$ & $\begin{array}{l}\text { undet. } \\
\text { undet. }\end{array}$ & & & & \\
\hline 165 & 47.4 & 49.4 & 2.0 & 0.024 & $<0.05$ & 3.5 & W & 46.5 & 47.5 & 1.0 \\
\hline 166 & $\begin{array}{l}40.3 \\
40.8 \\
41.8 \\
42.3 \\
40.5 \\
51.7 \\
54.2 \\
55.0\end{array}$ & $\begin{array}{l}40.8 \\
41.8 \\
42.3 \\
42.6 \\
50.5 \\
52.4 \\
54.5 \\
55.5\end{array}$ & $\begin{array}{c}0.5 \\
1.0 \\
0.5 \\
0.3 \\
10.01 \\
0.7 \\
0.3 \\
0.5\end{array}$ & $\begin{array}{l}0.012 \\
0.092 \\
0.34 \\
0.021 \\
0.016 \\
<0.01 \\
<0.01\end{array}$ & $\begin{array}{l}0.31 \\
0.44 \\
4.42 \\
0.46 \\
<0.1 \\
<0.1 \\
<0.1\end{array}$ & $\begin{array}{c}2.2 \\
0.5 \\
0.7 \\
0.1 \\
\overline{3.0} \\
\text { undet. } \\
\text { undet. }\end{array}$ & $\begin{array}{l}\mathrm{W} \\
\mathrm{W}\end{array}$ & $\begin{array}{l}39.3 \\
47.4 \\
50.2\end{array}$ & $\begin{array}{l}40.5 \\
48.5 \\
51.1\end{array}$ & $\begin{array}{l}1.1 \\
0.9\end{array}$ \\
\hline 167 & $\begin{array}{l}38.5 \\
40.1 \\
51.1\end{array}$ & $\begin{array}{l}39.3 \\
40.6 \\
52.9\end{array}$ & $\begin{array}{l}0.8 \\
0.5 \\
1.8\end{array}$ & $\begin{array}{l}0.006 \\
0.005 \\
0.011\end{array}$ & $\begin{array}{l}0.11 \\
0.17 \\
0.05\end{array}$ & $\begin{array}{l}2.8 \\
4.2 \\
4.6\end{array}$ & $w$ & 37.1 & 38.0 & 0.9 \\
\hline 168 & 35.1 & 35.3 & $0.2 \mathrm{I}$ & $<0.01$ & 0.05 & 3.2 & $\mathrm{~W}$ & 36.9 & 37.9 & 1.0 \\
\hline 171 & $\begin{array}{r}3.0 \\
7.2 \\
10.9 \\
16.3 \\
16.6 \\
28.9 \\
29.7 \\
31.9\end{array}$ & $\begin{array}{r}10.0 \\
9.9 \\
16.3 \\
16.6 \\
16.9 \\
29.7 \\
30.2 \\
32.5\end{array}$ & $\begin{array}{l}7.01 / \\
2.7 \\
5.4 \\
0.3 \\
0.3 \\
0.8 \\
0.5 \\
0.64\end{array}$ & $\begin{array}{l}- \\
0.028 \\
0.024 \\
1.22 \\
0.22 \\
0.068 \\
0.008 \\
0.034\end{array}$ & $\begin{array}{l}- \\
0.22 \\
0.17 \\
3.0 \\
2.42 \\
0.11 \\
0.11 \\
0.10\end{array}$ & $\begin{array}{r}-1.8 \\
1.0 \\
1.4 \\
0.2 \\
4.9 \\
5.6 \\
14.2\end{array}$ & $\begin{array}{l}W \\
S \\
W \\
\text { VS } \\
S\end{array}$ & $\begin{array}{r}6.0 \\
6.9 \\
7.9 \\
13.8 \\
27.3 \\
30.1\end{array}$ & $\begin{array}{r}6.9 \\
7.9 \\
13.8 \\
14.9 \\
28.3 \\
31.0\end{array}$ & $\begin{array}{l}0.9 \\
1.0 \\
5.9 \\
1.1 \\
1.0 \\
0.9\end{array}$ \\
\hline
\end{tabular}




\section{OFFICIAL USE ONLY}

47

Table 3.--Assay and gamma-ray data, Upper group area, San Miguel County, Colorado--Continued

\begin{tabular}{|c|c|c|c|c|c|c|c|}
\hline \multirow[b]{2}{*}{ Hole No. } & \multicolumn{4}{|c|}{ Assay data } & \multicolumn{3}{|c|}{ Gamma-ray data } \\
\hline & $\frac{\text { Depth in feet }}{\text { From }}$ & Thickness & & $\frac{\text { Percent }}{\mathrm{V}}$ & Gamma-ray & Depth in feet & $\begin{array}{c}\text { Thickness } \\
\text { (feet) }\end{array}$ \\
\hline
\end{tabular}

Block I (Big Four, Canyon View, Grant, Sunnyside claims, and public land -- continued)

\begin{tabular}{|c|c|c|c|c|c|c|c|c|c|}
\hline $\begin{array}{l}18.2 \\
30.0 \\
56.4 \\
57.7 \\
59.2\end{array}$ & $\begin{array}{l}18.9 \\
35.0 \\
56.7 \\
58.2 \\
59.7\end{array}$ & $\begin{array}{l}0.7 \mathrm{~L} / \\
5.0 \mathrm{l} \\
0.3 \\
0.5 \\
0.5\end{array}$ & $\begin{array}{c}<0.01 \\
<0.01 \\
<0.01 \\
0.014\end{array}$ & $\begin{array}{l}0.06 \\
0.06 \\
0.08 \\
0.10\end{array}$ & $\begin{array}{c}\text { undet. } \\
1.4 \\
\text { undet. } \\
7.8\end{array}$ & W & 30.5 & 31.3 & 0.8 \\
\hline $\begin{array}{r}6.1 \\
7.5 \\
8.1 \\
9.1 \\
9.6 \\
10.6 \\
39.7 \\
40.3 \\
48.4 \\
53.2 \\
60.0\end{array}$ & $\begin{array}{r}7.2 \\
8.1 \\
9.1 \\
9.6 \\
10.6 \\
11.1 \\
40.0 \\
40.8 \\
52.4 \\
53.9 \\
60.5\end{array}$ & $\begin{array}{l}1.1 \mathrm{3} / \\
0.6 \\
1.0 \\
0.5 \\
1.0 \\
0.5 \\
0.34 / \\
0.5 \\
4.0 \\
0.7 \\
0.5\end{array}$ & $\begin{array}{c}0.004 \\
0.003 \\
0.17 \\
0.002 \\
0.13 \\
0.03 \\
<0.01 \\
0.006 \\
0.014 \\
0.006 \\
0.02\end{array}$ & $\begin{array}{r}0.20 \\
0.20 \\
0.28 \\
0.34 \\
2.80 \\
1.91 \\
<0.1 \\
<0.1 \\
<0.1 \\
<0.1 \\
<0.1\end{array}$ & $\begin{array}{r}0.3 \\
14.2 \\
5.6 \\
3.9 \\
0.9 \\
0.9 \\
\text { undet. } \\
1.8 \\
3.1 \\
2.9 \\
13.7\end{array}$ & $\begin{array}{l}2 / \\
S \\
W \\
S \\
W \\
W\end{array}$ & $\begin{array}{r}0.8 \\
8.9 \\
9.8 \\
10.5 \\
38.5 \\
47.9\end{array}$ & $\begin{array}{r}8.9 \\
9.8 \\
10.5 \\
11.5 \\
40.4 \\
52.3\end{array}$ & $\begin{array}{l}8.1 \\
0.9 \\
0.7 \\
1.0 \\
1.9 \\
4.4\end{array}$ \\
\hline 47.4 & 47.9 & 0.5 & $<0.01$ & 0.06 & undet. & Barren & & & \\
\hline $\begin{array}{l}3.0 \\
6.1\end{array}$ & 6.1 & $\begin{array}{l}3.1 \mathrm{I} \\
1.4\end{array}$ & 0.017 & - & -- & $\begin{array}{l}W \\
S \\
W\end{array}$ & $\begin{array}{l}3.2 \\
5.4 \\
5.7\end{array}$ & $\begin{array}{l}5.4 \\
5.7 \\
7.0\end{array}$ & $\begin{array}{l}2.2 \\
0.3 \\
1.3\end{array}$ \\
\hline 62.0 & 62.3 & 0.3 & $<0.01$ & $<0.05$ & undet. & & & & \\
\hline 68.9 & 69.2 & 0.3 & 0.009 & 0.14 & 2.4 & & & & \\
\hline $\begin{array}{l}27.0 \\
69.3 \\
71.3 \\
72.6\end{array}$ & $\begin{array}{l}27.3 \\
71.1 \\
72.1 \\
72.9\end{array}$ & $\begin{array}{l}0.3 \\
1.8 \\
0.84 \\
0.3\end{array}$ & $\begin{array}{r}0.007 \\
0.019 \\
0.017 \\
<0.01\end{array}$ & $\begin{array}{r}0.13 \\
0.06 \\
<0.05 \\
<0.05 \\
\text { OFFICIA }\end{array}$ & $\begin{array}{r}1.0 \\
3.6 \\
8.4 \\
\text { undet. }\end{array}$ & W & 68.7 & 69.1 & 0.4 \\
\hline
\end{tabular}




\section{OFFICTAL USE ONLY}

Table 3.--Assay and gamma-ray data, Upper group area, San Miguel County, Colorado--Continued

\begin{tabular}{c} 
Assay data \\
Hole No. Depth in feet Thickness \\
\cline { 2 - 3 }
\end{tabular}

\begin{tabular}{lll} 
& Gamma-ray data \\
\hline Gammá-ray & Depth in feet & Thickness \\
intensity & From $\quad \underline{\text { To }}$ & (feet)
\end{tabular}

Block 1 (Big Four, Canyon View, Grant, Sunnyside claims, and public land -- continued)

$$
\begin{array}{llllllll}
186 & 80.4 & 81.2 & 0.8 & 4 / & 0.017 & <0.05 & 3.0 \\
& 91.1 & 91.7 & 0.6 & 4 & 0.015 & <0.05 & 20.7
\end{array}
$$

Block 2 (Grant and Canyon View claims)

102

$\begin{array}{rrr}5.9 & 6.6 & 0 . \\ 7.4 & 8.6 & 1 . \\ 8.6 & 10.0 & 1 . \\ 10.0 & 10.3 & 0 . \\ 10.3 & 12.6 & 2 . \\ 12.9 & 13.8 & 0 . \\ 29.9 & 30.2 & 0 .\end{array}$

151

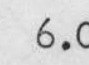

9.2

3.2

30.2

0.6

\subsection{8}

$$
0.020
$$$$
0.060
$$

0.20

0.027

$<0.01$

4) 0.011

152

29.6

0.013

Block 3 (Canyon View and Black Fox claims)$$
118
$$

\begin{tabular}{|c|c|c|c|}
\hline $\begin{array}{l}37.9 \\
39.0 \\
40.2 \\
42.6 \\
47.2 \\
52.4 \\
53.6 \\
54.4\end{array}$ & $\begin{array}{l}39.0 \\
40.2 \\
42.6 \\
43.1 \\
49.7 \\
53.1 \\
54.1 \\
54.6\end{array}$ & $\begin{array}{l}1.1 \\
1.2 \\
2.4 \quad 4 \\
0.5 \\
2.5 \\
0.7 \\
0.5 \\
0.2\end{array}$ & $\begin{array}{c}0.016 \\
0.12 \\
0.039 \\
0.045 \\
0.016 \\
<0.01 \\
<0.01 \\
<0.01\end{array}$ \\
\hline
\end{tabular}$$
\begin{aligned}
& 32.8 \\
& 33.3
\end{aligned}
$$$$
\begin{aligned}
& 33.3 \\
& 34.3
\end{aligned}
$$$$
0.5
$$$$
0.024
$$$$
0.041
$$

124
0.96

0.13

0.67

0.34
0.11

0.11

0.07

0.4

0.4$$
0.45
$$$$
1.09
$$$$
2.1
$$

$\begin{array}{llll}2 / & 0.0 & 4.7 & 4.7\end{array}$

$\begin{array}{lll}4.7 & 5.6 & 0.9\end{array}$

$\begin{array}{lll}7.6 & 8.6 & 1.0\end{array}$

$\begin{array}{lll}9.6 & 12.3 & 2.7\end{array}$

$\begin{array}{llll}S & 7.5 & 8.1 & 0.6\end{array}$

$0.05 \quad 3.8$

$\begin{array}{ll}0.08 & 1.9 \\ 2.62 & 0.4 \\ 0.34 & 1.6 \\ 1.8 & 0.3 \\ 0.13 & 2.1 \\ 0.08 & \text { undet. } \\ 0.08 & \text { undet. } \\ 0.10 & \text { undet. }\end{array}$

OFFICIAL USE ONLY 


\section{OFFICIAL USE ONLY}

Table 3.--Assay and gamma-ray data, Upper group area, San Niguel County, Colorado--Continued

\begin{tabular}{|c|c|c|}
\hline Hole No. & Depth in feet & Thickness \\
\hline & From $\quad$ To & (feet) \\
\hline
\end{tabular}

$\begin{array}{lll} & \text { Gamma-ray data } \\ \text { Gamma-ray } & \text { Depth in feet } & \text { Thickness } \\ \text { intensity } & \text { From } & \text { (feet) }\end{array}$

Block 3 (Canyon View and Black Fox claims -- continued)

28

$$
46.6
$$$$
47.10 .5
$$

47.4 54.6

$$
\begin{array}{lll}
48.1 & 0.7 \\
55.1 & 0.5 & 0.024 \\
& 0.024
\end{array}
$$$$
0.5
$$$$
0.015
$$

0.024$$
40.50 .31 /<0.01
$$$$
130
$$

43.0

45.7

47.2

48.4

$\begin{array}{ll}43.5 & 0.5\end{array}$

$47.2 \quad 1.5$

$48.4 \quad 1.2$

$\begin{array}{ll}49.1 & 0.7\end{array}$

$52.9 \quad 3.3$

53.9

$\begin{array}{lll}54.7 & 0.8\end{array}$

0.018

0.045

0.058

0.015

0.016

0.014

132

$$
\begin{aligned}
& 3.0 \\
& 4.0 \\
& 6.2
\end{aligned}
$$$$
\begin{array}{lll}
4.0 & 1.01 / & 1.00 \\
5.7 & 1.7 & 0.015 \\
6.7 & 0.5 & 0.005
\end{array}
$$

Other holes (Canyon View claims)

111

$\begin{array}{rrrrr}25.0 & 27.0 & 2.01 / & -. .- \\ 27.0 & 27.9 & 0.9 & 0.004 \\ 27.9 & 33.4 & 5.51 / & \overline{0.003} \\ 33.4 & 33.7 & 0.31 / & 0.003 \\ 40.0 & 50.0 & 10.01 / & \ldots\end{array}$

116

42.8

43.3

0.5

0.016

\begin{tabular}{ll}
0.08 & 0.8 \\
\hdashline 0.13 & 1.4 \\
\hdashline---
\end{tabular}

0.11

3.4

Other holes (Black Fox claim)

\begin{abstract}
2.0
\end{abstract}

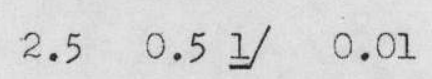

$<0.05$

2.5

W

0.0

$4.1 \quad 4.1$$$
0.33
$$$$
4.4
$$$$
0.90
$$

$$
0.13
$$$$
2.5
$$$$
<0.05
$$$$
\text { undet. }
$$

0.09

0.64

3.8

3.8

$0.24 \quad 5.0$

$0.20 \quad 3.2$$$
2.0
$$

3.60

0.22

1.6

4.3

8.6

$\begin{array}{rrr}44.8 & 46.3 & 1.5 \\ 46.3 & 46.6 & 0.3 \\ 53.3 & 53.9 & 0.6 \\ 39.9 & 41.0 & 1.1 \\ 39.2 & 45.2 & 6.0 \\ 45.2 & 46.8 & 1.6 \\ 46.8 & 50.4 & 3.6 \\ 50.4 & 51.0 & 0.6 \\ & & \\ 1.5 & 3.5 & 2.0 \\ 3.5 & 14.4 & 10.9\end{array}$

25.5

$26.1 \quad 0.6$

$\begin{array}{lll}27.5 & 28.8 & 1.3\end{array}$

$\begin{array}{lll}30.2 & 31.0 & 0.8\end{array}$

$\begin{array}{lll}33.6 & 35.2 & 1.6\end{array}$

OFFICIAI USE ONLY 


\section{OFFICIAL USE ONLY}

50

Table 3.--Assay and gamma-ray data, Upper group area, San Miguel County, Colorado-Continued

\begin{tabular}{|c|c|c|c|}
\hline Hole No. & Depth in feet & Thickness & Percent \\
\hline & From $\quad$ To & (feet) & $\mathrm{V}_{2} \mathrm{O}_{5} \quad \mathrm{CaCO}_{3}$ \\
\hline
\end{tabular}

$\begin{array}{lll} & \text { Gamma-ray data } & \\ \text { Gamma-ray } & \text { Depth in feet } & \text { Thickness } \\ \text { intensity } & \text { From } \quad \text { To } & \text { (feet) }\end{array}$

Block 4 (Canyon View, Jessie claims and public land)

134

$\begin{array}{ll}70.9 & 71.8 \\ 72.9 & 77.2 \\ 84.0 & 85.0 \\ 85.0 & 86.8 \\ 86.8 & 87.0 \\ 87.0 & 88.3\end{array}$

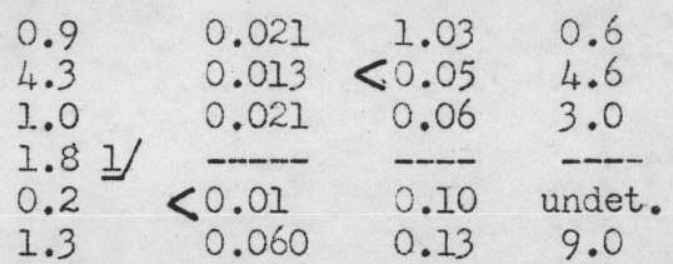

141

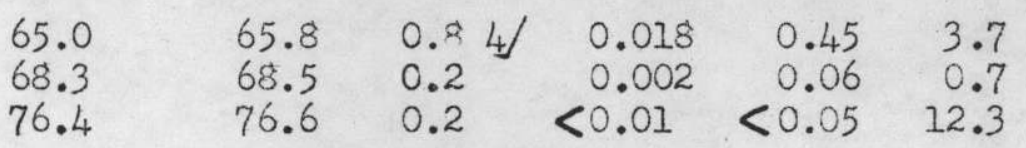

144

$\begin{array}{llllll}55.0 & 60.0 & 5.01 / & -\cdots & -- & -- \\ 66.2 & 67.2 & 1.0 & 0.018 & 0.11 & 2.6 \\ 67.2 & 68.7 & 1.5 & 0.055 & 0.14 & 3.4 \\ 68.7 & 69.7 & 1.0 & 0.009 & 0.20 & 2.2 \\ 73.8 & 76.8 & 3.0 & 0.018 & 0.15 & 3.8 \\ 78.4 & 78.9 & 0.54 & 0.014 & 0.13 & 6.2\end{array}$

Block 5 (Jessie, Colorado Maiden, Black Bell claims)

$\begin{array}{lllllll}131 & 60.0 & 63.4 & 3.41 & \ldots & \ldots & - \\ 63.4 & 64.9 & 1.5 & 0.018 & 0.14 & 6.7 \\ 64.9 & 65.9 & 1.0 & 0.05 & 0.11 & 5.8 \\ 65.9 & 68.1 & 2.2 & 0.033 & <0.05 & 8.9\end{array}$

$\begin{array}{lll}68.4 & 72.4 & 4.0 \\ 73.7 & 75.7 & 2.0 \\ 82.2 & 83.0 & 0.8 \\ 85.1 & 86.0 & 0.9 \\ & & \\ & & \\ 63.7 & 64.2 & 0.5 \\ 66.2 & 67.2 & 1.0 \\ & & \\ 56.3 & 56.6 & 0.3 \\ 65.7 & 67.1 & 1.4 \\ 73.1 & 73.8 & 0.7 \\ 76.8 & 78.2 & 1.4\end{array}$

$\begin{array}{lll}61.8 & 62.2 & 0.4 \\ 62.2 & 62.6 & 0.4 \\ 62.6 & 64.5 & 1.9 \\ 64.5 & 64.9 & 0.4 \\ 64.9 & 65.7 & 0.8 \\ 65.7 & 66.5 & 0.6\end{array}$


Table 3.--Assay and gamma-ray, Upper group area, San Miguel County, Colorado--Continued

\begin{tabular}{c} 
Assay data \\
Hole No. Depth in feet Thickness \\
\cline { 2 - 3 }
\end{tabular}

\begin{tabular}{lll} 
& Gamma-ray data \\
\hline Gamma-ray & Depth in feet & \\
intensity & From $\quad$ To & (feet)
\end{tabular}

Block 5 (Jessie, Colorado Kaiden, Black Bell claims -- continued)

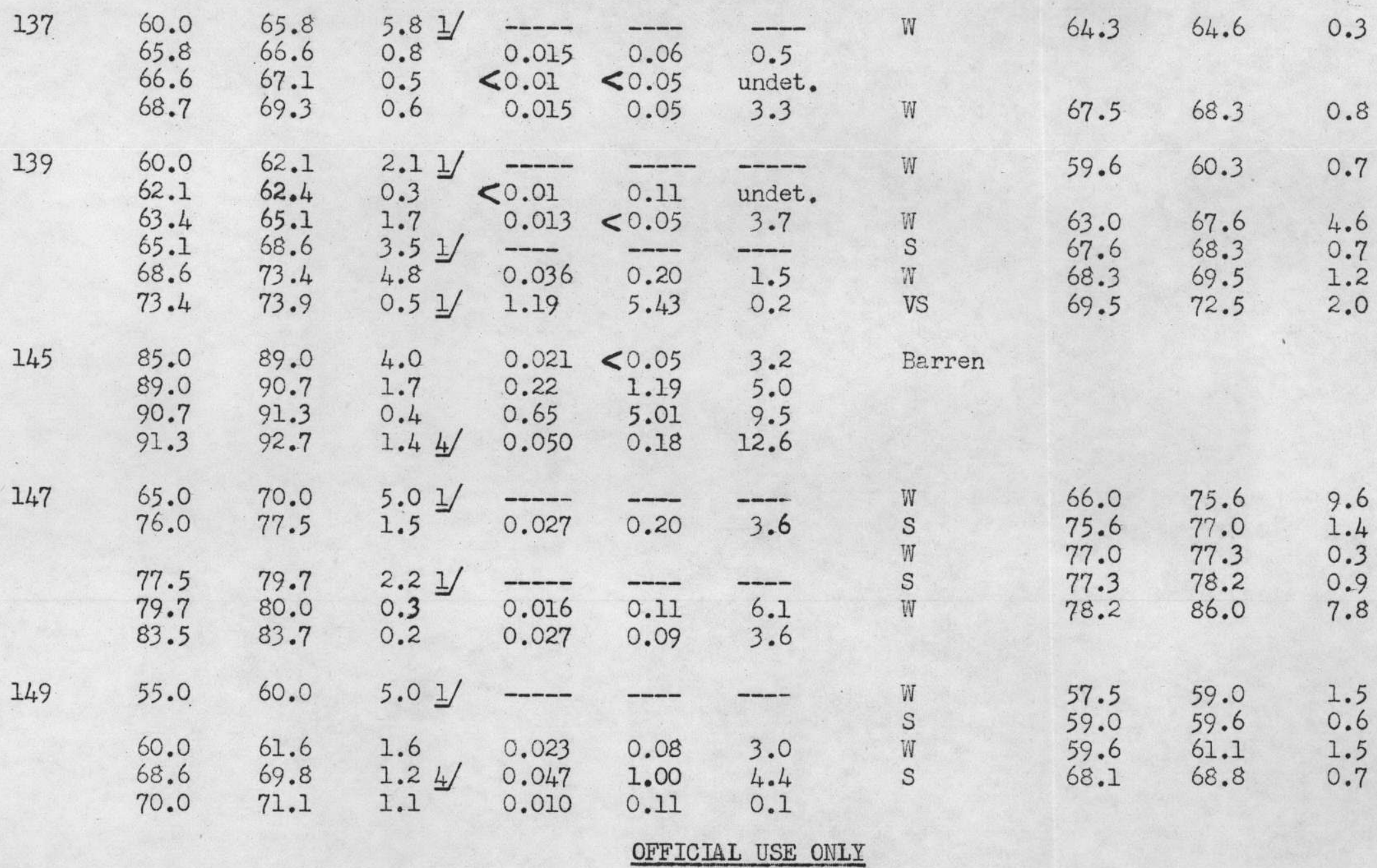


Table 3.--Assay and gamma-ray, Upper group area, San Miguel County, Colorado-Continued

\begin{tabular}{|c|c|c|c|c|}
\hline Hole No. & Depth in feet & Thickness & Percent & \\
\hline & From To & (feet) & $\mathrm{V}_{2} \mathrm{O}_{5}$ & $\overline{\mathrm{CaCO}_{3}}$ \\
\hline
\end{tabular}

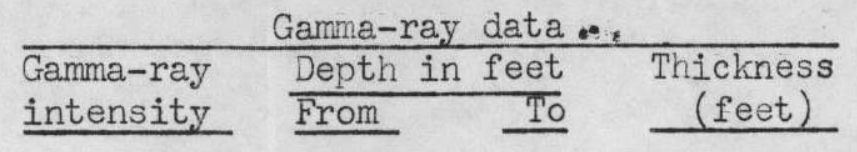

Block 6 (Jessie claim)

$\begin{array}{rrrrrr}42.6 & 43.3 & 0.7 & <0.01 & 0.32 & 7.0 \\ 60.3 & 62.0 & 1.7 & 0.020 & <0.05 & 5.0\end{array}$

Other holes (Jessie claim)

$\begin{array}{lllllllllll}127 & 93.6 & 94.3 & 0.74 / & 0.011 & 0.06 & 6.7 & \text { W } & 91.5 & 92.1 & 0.6 \\ 143 & 20.0 & 30.0 & 10.01 / & \ldots & \ldots & \ldots & \text { W } & 24.2 & 25.2 & 1.0\end{array}$

Block 7 (University claim)

$\begin{array}{rrrrrrrr}138 & 36.2 & 41.3 & 5.1 & <0.01 & 0.17 & \text { undet. } & \text { Not probed } \\ 41.8 & 42.1 & 0.3 & <0.01 & 0.18 & \text { undet. } \\ 44.6 & 45.6 & 1.0 & 0.017 & 0.54 & 3.9 \\ 45.9 & 46.9 & 1.0 & 0.011 & <0.05 & 12.5\end{array}$

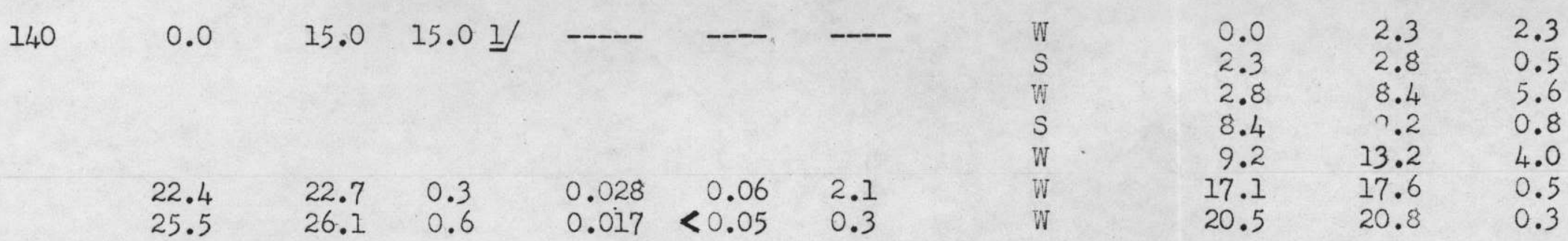

Block 8 (Black Belle)

$\begin{array}{lllllllllll}172 & 33.2 & 38.2 & 5.0 & 0.015 & 0.14 & 4.3 & \text { W } & 32.3 & 36.3 & 4.0 \\ 174 & 37.8 & 39.6 & 1.81 / & 0.028 & 0.17 & 1.5 & \text { S } & 36.4 & 37.2 & 0.8 \\ & 45.0 & 45.4 & 0.4 \pm & 0.016 & 0.14 & 2.4 & \text { W } & 43.7 & 44.2 & 0.5 \\ & & & & & & & \end{array}$


Table 30--Assay and gemma-ray, Upper group area, 53 San Miguel County, Colorado-Continued

Hole No. Depth in feet $\frac{\text { Assay data }}{\text { Thickness }}$

\begin{tabular}{lll} 
& Gamma-ray data \\
\hline Gamma-ray & Depth in feet & \\
intensity & From
\end{tabular}

Block 9. (Black Belle claim)

$\begin{array}{lllllll}176 & 39.5 & 41.1 & 1.6 & 0.021 & 0.17 & 8.0 \\ 50.0 & 55.0 & 5.01 & - & - & -\end{array}$

Other holes (Black Belle claim)

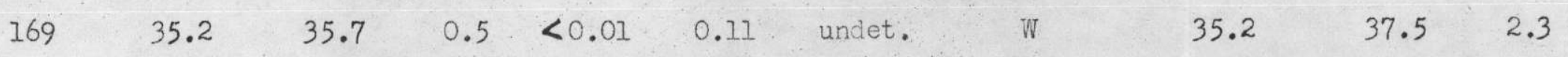

Other holes (public land)

$\begin{array}{lllllll}163 & 203.5 & 203.8 & 0.3 & 0.022 & 0.05 & 2.3\end{array}$




\section{OFFICILL USE ONLY}

Table 2.--Indicated and inferred reserves $1 /$ of the Upper group area,

San Miguel County, Colorado

(Attributed to U. S. G. S. drilling 1948-1950)

\begin{tabular}{|c|c|c|c|c|c|c|c|c|c|c|c|c|c|c|c|c|c|c|c|}
\hline \multirow{3}{*}{$\begin{array}{r}\text { Block } \\
\text { number }\end{array}$} & \multirow{3}{*}{ Location } & \multicolumn{9}{|c|}{ Indicated reserves } & \multicolumn{9}{|c|}{ Inferred reserves } \\
\hline & & \multicolumn{3}{|c|}{$\begin{array}{l}\text { Grade cut-off } \\
0.10 \% \mathrm{U}_{3} \mathrm{O}_{8} \text { or } 1.0 \% \mathrm{~V}_{2} \mathrm{O}_{5}\end{array}$} & \multicolumn{3}{|c|}{$\begin{array}{l}\text { Grade cut-off } \\
0.05 \% \mathrm{U}_{3} \mathrm{O}_{8} \text { or } 0.56 \mathrm{~V}_{2} \mathrm{O}_{5}\end{array}$} & \multicolumn{3}{|c|}{$\begin{array}{l}\text { Grade cut-off } \\
0.02 \% \mathrm{U}_{3} \mathrm{O}_{8} \text { or } 0.2 \% \mathrm{~V}_{2} \mathrm{O}_{5}\end{array}$} & \multicolumn{3}{|c|}{$\begin{array}{c}\text { Grade cut-off } \\
0.10 \% \mathrm{U}_{3} \mathrm{O}_{8} \text { or } 1.0 \% \mathrm{~V}_{2} \mathrm{O}_{5}\end{array}$} & \multicolumn{3}{|c|}{$\begin{array}{l}\text { Grade cut-off } \\
0.05 \% \mathrm{U}_{3} \mathrm{O}_{8} \text { or } 0.5 \% \mathrm{~V}_{2} \mathrm{O}_{5}\end{array}$} & \multicolumn{3}{|c|}{$\begin{array}{l}\text { Grade cut-off } \\
0.02,6 \mathrm{U}_{3} \mathrm{O}_{8} \text { or } 0.26 \mathrm{~V}_{2} \mathrm{O}_{5}\end{array}$} \\
\hline & & $\begin{array}{l}\text { Short } \\
\text { tons }\end{array}$ & $\frac{\text { Perc }}{\mathrm{U}_{3} \mathrm{O}_{8}}$ & $\frac{\text { ent }}{\mathrm{V}_{2} \mathrm{O}_{5}}$ & $\begin{array}{l}\text { Short } \\
\text { tons }\end{array}$ & $\frac{\text { Per }}{\mathrm{U}_{3} \mathrm{O}_{8}}$ & $\frac{\text { ent }}{V_{2} \mathrm{O}_{5}}$ & $\begin{array}{l}\text { Short } \\
\text { tons }\end{array}$ & $\frac{\text { Perc }}{\mathrm{U}_{3} \mathrm{O}_{8}}$ & $\frac{\text { ent }}{\mathrm{V}_{2} \mathrm{O}_{5}}$ & $\begin{array}{l}\text { Short } \\
\text { tons }\end{array}$ & $\frac{\text { Perce }}{\mathrm{U}_{3} \mathrm{O}_{8}}$ & $\frac{\mathrm{n}_{2}}{\mathrm{~V}_{2} \mathrm{O}_{5}}$ & $\begin{array}{l}\text { Short } \\
\text { tons }\end{array}$ & $\frac{\text { Perce }}{\mathrm{U}_{3} \mathrm{O}_{8}}$ & $\frac{\text { ent }}{\mathrm{V}_{2} \mathrm{O}_{5}}$ & $\begin{array}{l}\text { Short } \\
\text { tons }\end{array}$ & $\frac{\text { Perce }}{\mathrm{U}_{3} \mathrm{O}_{8}}$ & $\frac{n t}{V_{2} O_{5}}$ \\
\hline 1 & $\begin{array}{l}\text { Big Four, Canyon View } \\
\text { and Sunnyside claims } \\
\text { and public land }\end{array}$ & 5,000 & 0.19 & 1.6 & 8,000 & 0.13 & 1.2 & 16,700 & 0.08 & 0.72 & 3,000 & 0.22 & 1.6 & 4,600 & 0.15 & 1.2 & 15,000 & 0.07 & 0.52 \\
\hline 2 & $\begin{array}{l}\text { Canyon View and Grant } \\
\text { claims }\end{array}$ & & & & & & & & & & & & & 100 & 0.085 & 0.61 & 1,700 & 0.027 & 0.31 \\
\hline 3 & $\begin{array}{l}\text { Black Fox and Canyon View } \\
\text { claims }\end{array}$ & & & & & & & 1,000 & 0.03 & 0.53 & 250 & 0.18 & 2.4 & 550 & 0.11 & 1.4 & 1,500 & 0.05 & 0.65 \\
\hline 4 & $\begin{array}{l}\text { Canyon View and Jessie } \\
\text { claims }\end{array}$ & & & & & & & & & & & & & 700 & 0.057 & 0.14 & 900 & 0.046 & 0.14 \\
\hline 5 & $\begin{array}{l}\text { Black Belle, Canyon View } \\
\text { and Jessie claims }\end{array}$ & & & & & & & & & & 250 & 0.26 & 2.1 & 800 & 0.12 & 0.83 & 1,800 & 0.09 & 0.51 \\
\hline 6 & Jessie claim & & & & & & & & & & & & & & & & 200 & 0.028 & 0.17 \\
\hline 7 & University claim & & & & & & & & & & & & & 150 & 0.017 & 0.54 & 150 & 0.017 & 0.54 \\
\hline 8 & Black Belle claim & & & & & & & & & & & & & & & & 200 & 0.028 & 0.17 \\
\hline 9 & Black Belle claim & & & & & & & & & & & & & & & & 200 & 0.021 & 0.17 \\
\hline & $\begin{array}{l}\text { Totals and averages } \\
\text { (rounded) }\end{array}$ & 5,000 & 0.19 & 1.6 & 8,000 & 0.13 & 1.2 & 17,700 & 0.07 & 0.7 & 3,500 & 0.22 & 1.7 & 7,000 & 0.13 & 1.0 & 21,600 & 0.06 & 0.5 \\
\hline
\end{tabular}

1f One foot or more thick 


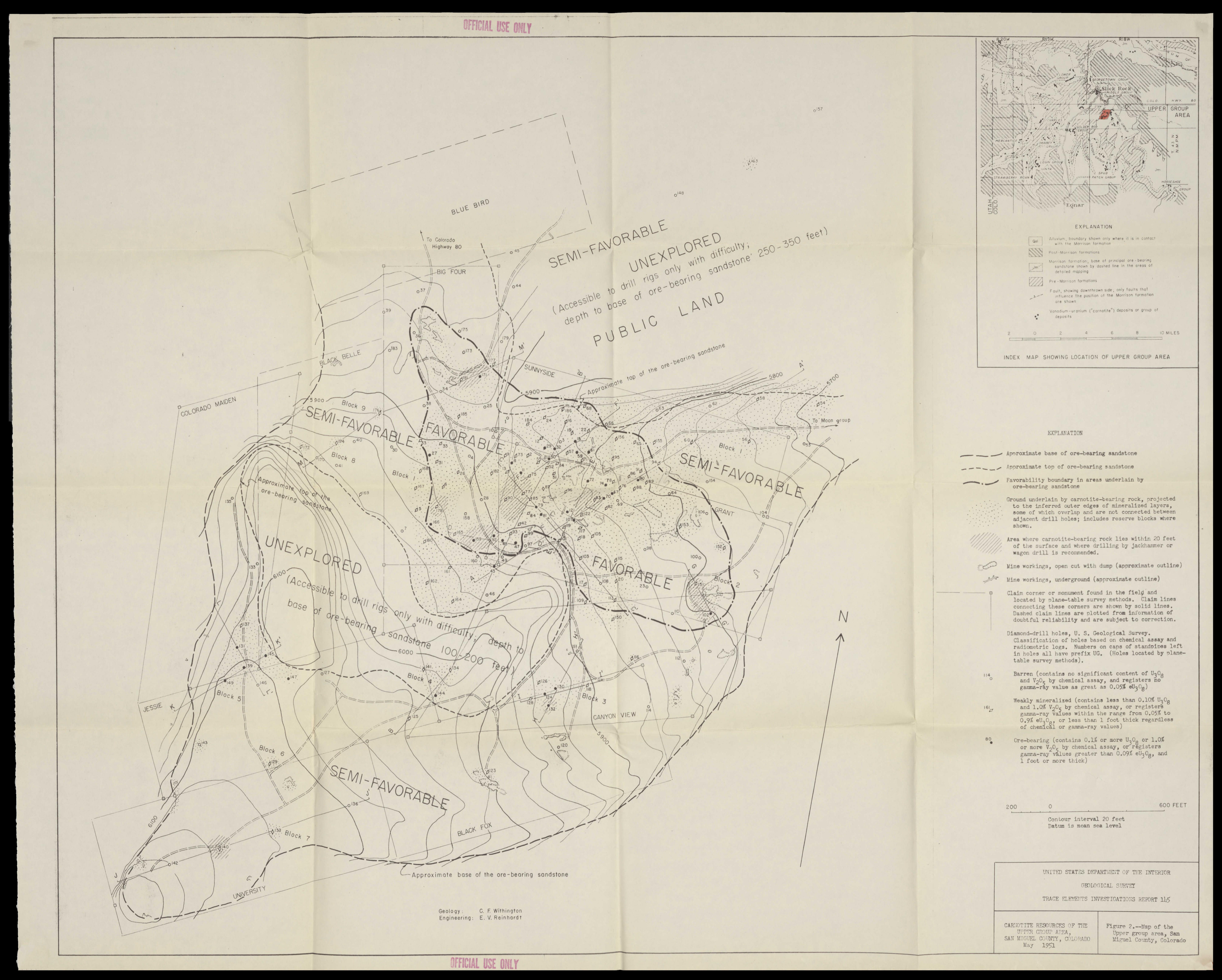




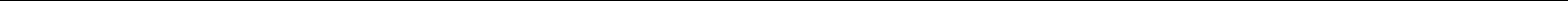



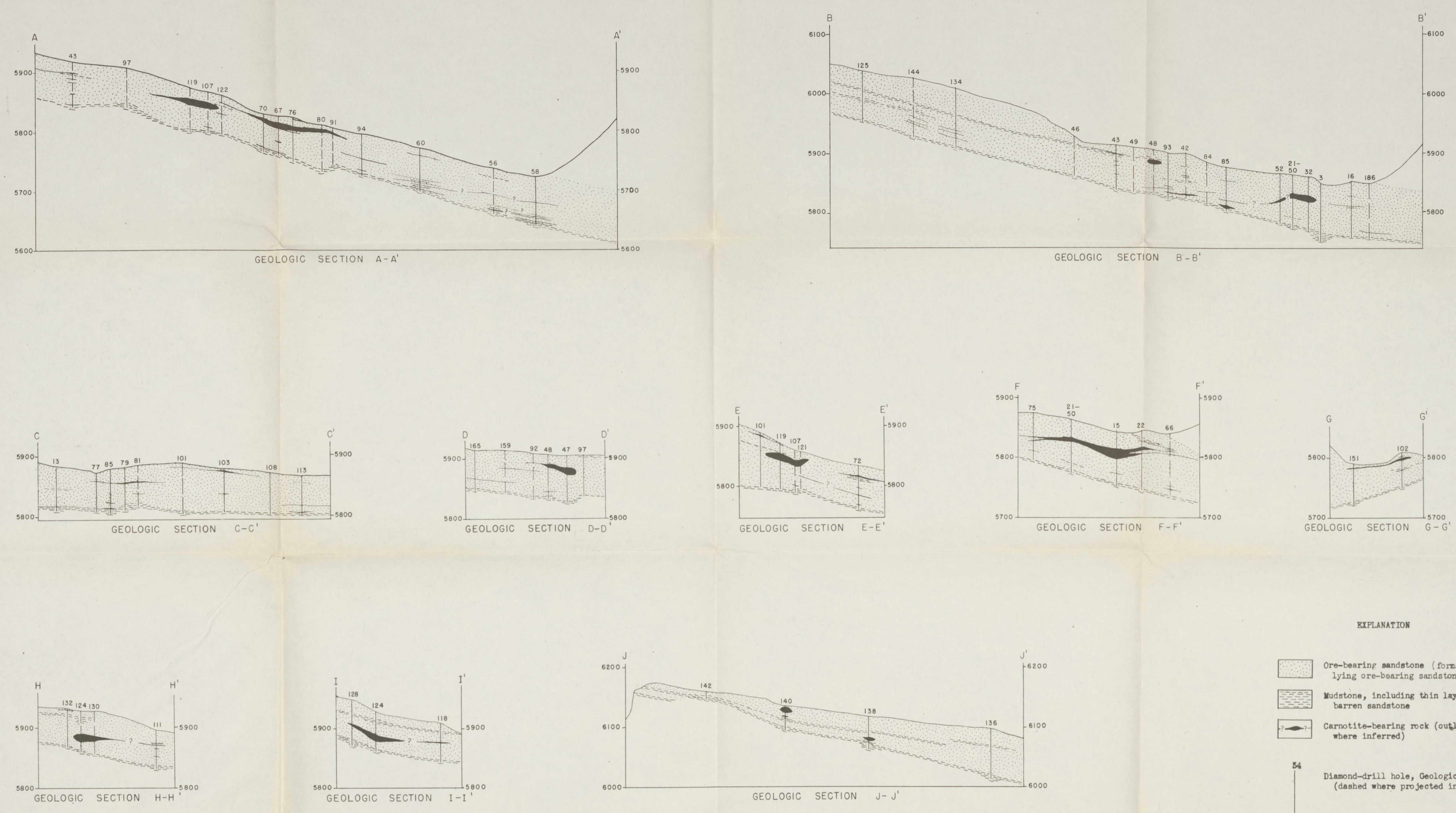

RPPLANATION
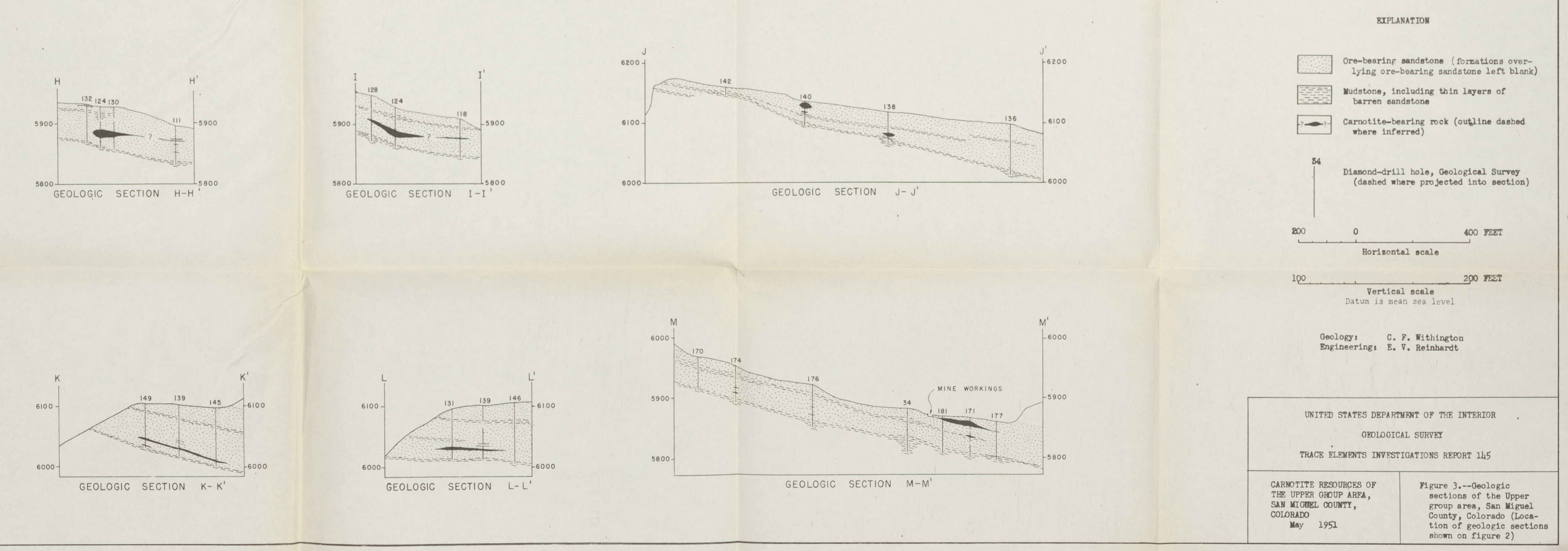


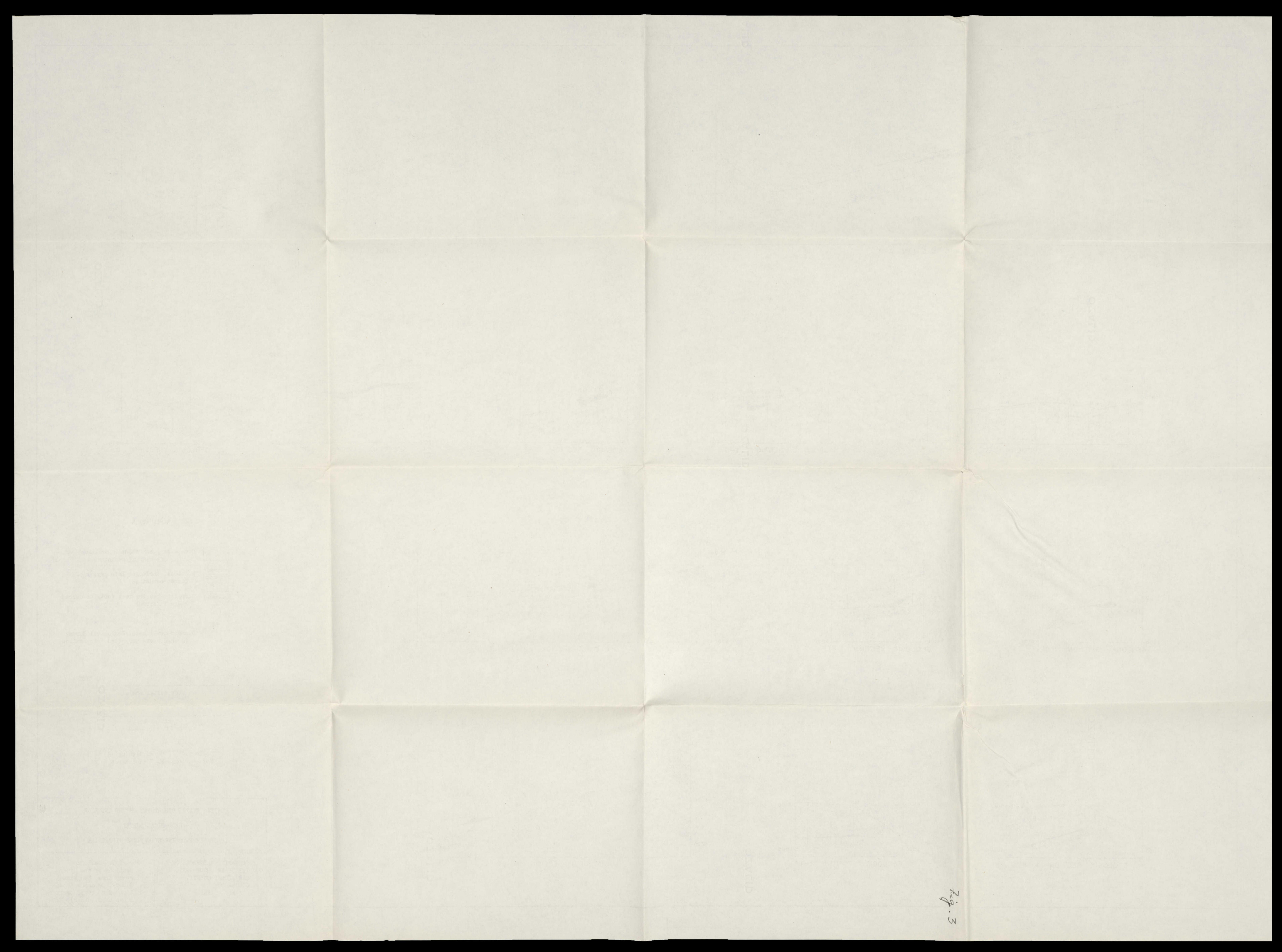


